University of Nebraska - Lincoln

DigitalCommons@University of Nebraska - Lincoln

Publications from USDA-ARS / UNL Faculty

U.S. Department of Agriculture: Agricultural

Research Service, Lincoln, Nebraska

2014

The use of electromagnetic induction techniques in soils studies

James A. Doolittle

USDA-NRCS-NSSC, jim.doolittle@lin.usda.gov

Eric C. Brevik

Dickinson State University, Eric.Brevik@dickinsonstate.edu

Follow this and additional works at: https://digitalcommons.unl.edu/usdaarsfacpub

Doolittle, James A. and Brevik, Eric C., "The use of electromagnetic induction techniques in soils studies" (2014). Publications from USDA-ARS / UNL Faculty. 1462.

https://digitalcommons.unl.edu/usdaarsfacpub/1462

This Article is brought to you for free and open access by the U.S. Department of Agriculture: Agricultural Research Service, Lincoln, Nebraska at DigitalCommons@University of Nebraska - Lincoln. It has been accepted for inclusion in Publications from USDA-ARS / UNL Faculty by an authorized administrator of DigitalCommons@University of Nebraska - Lincoln. 
Review

\title{
The use of electromagnetic induction techniques in soils studies
}

\author{
James A. Doolittle ${ }^{\mathrm{a}}$, Eric C. Brevik ${ }^{\mathrm{b}, *}$ \\ a USDA-NRCS-NSSC, 11 Campus Boulevard, Suite 200, Newtown Square, PA 19073, United States \\ b Department of Natural Sciences, 291 Campus Drive, Dickinson State University, Dickinson, ND 58601, United States
}

\section{A R T I C L E I N F O}

Article history:

Received 29 October 2013

Received in revised form 23 January 2014

Accepted 26 January 2014

Available online 4 March 2014

\section{Keywords:}

Electromagnetic induction

Apparent conductivity

Soil mapping

Soil spatial characterization

\begin{abstract}
A B S T R A C T
Electromagnetic induction (EMI) has been used to characterize the spatial variability of soil properties since the late 1970s. Initially used to assess soil salinity, the use of EMI in soil studies has expanded to include: mapping soil types; characterizing soil water content and flow patterns; assessing variations in soil texture, compaction, organic matter content, and pH; and determining the depth to subsurface horizons, stratigraphic layers or bedrock, among other uses. In all cases the soil property being investigated must influence soil apparent electrical conductivity $\left(\mathrm{EC}_{\mathrm{a}}\right.$ ) either directly or indirectly for EMI techniques to be effective. An increasing number and diversity of EMI sensors have been developed in response to users' needs and the availability of allied technologies, which have greatly improved the functionality of these tools. EMI investigations provide several benefits for soil studies. The large amount of georeferenced data that can be rapidly and inexpensively collected with EMI provides more complete characterization of the spatial variations in soil properties than traditional sampling techniques. In addition, compared to traditional soil survey methods, EMI can more effectively characterize diffuse soil boundaries and identify areas of dissimilar soils within mapped soil units, giving soil scientists greater confidence when collecting spatial soil information. EMI techniques do have limitations; results are site-specific and can vary depending on the complex interactions among multiple and variable soil properties. Despite this, EMI techniques are increasingly being used to investigate the spatial variability of soil properties at field and landscape scales.
\end{abstract}

(C) 2014 Elsevier B.V. All rights reserved.

\section{Contents}

1. Introduction $\ldots \ldots, \ldots, \ldots$

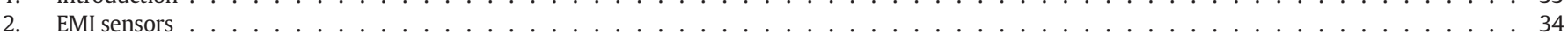

3. History . . . . . . . . . . . . . . . . . . . . . . . . . . . . . . . . . . . . 34

4. Applications . . . . . . . . . . . . . . . . . . . . . . . . . . . . . . . . . . . . . 35

4.1. A surrogate measure for the assessment of soil properties . . . . . . . . . . . . . . . . . . . . . . . . . . . . . . 35

4.1.1. Soil salinity . . . . . . . . . . . . . . . . . . . . . . . . . . . . . . . . . 36

4.1.2. Subsurface water movement and soluble salts . . . . . . . . . . . . . . . . . . . . . . . . . . . . . . . . . 36

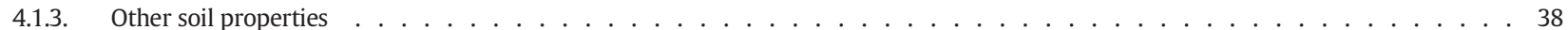

4.2. Refine and improve the quality of soil maps . . . . . . . . . . . . . . . . . . . . . . . . . . . . . . . . . . 38

4.3. A tool for soil-hydrologic studies . . . . . . . . . . . . . . . . . . . . . . . . . . . . . . . . . . . . 40

5. Summary .. . . . . . . . . . . . . . . . . . . . . . . . . . . . . . . . . . . . . . . . 42

References ... 42

\section{Introduction}

It is widely recognized that there is considerable variability within soils (Brevik et al., 2003; Doolittle et al., 1996; Miller, 2012). Electromagnetic induction (EMI) is widely used by soil scientists to better understand the spatial variability of soils and soil properties at field and landscape scales (Corwin, 2008; Toushmalani, 2010). Because of

\footnotetext{
* Corresponding author

E-mail addresses: jim.doolittle@lin.usda.gov (J.A. Doolittle), Eric.Brevik@dickinsonstate.edu (E.C. Brevik).
}

its speed, ease of use, relatively low cost, and volume of data collected, EMI has immense advantages over traditional methods used to collect soil information. Recent improvements in instrumentation and integration with other technologies (global-positioning systems (GPS), data processing software, and surface mapping programs) have fostered the expanded use of EMI in soils applications. The impetus for this expanded use has been the need for more accurate soil maps than those provided by traditional mapping techniques (Batte, 2000; Brevik et al., 2003, 2012) and the demonstrated efficiency of EMI to improve the accuracy and reliability of soil maps and provide more detailed information on soils and soil properties. 


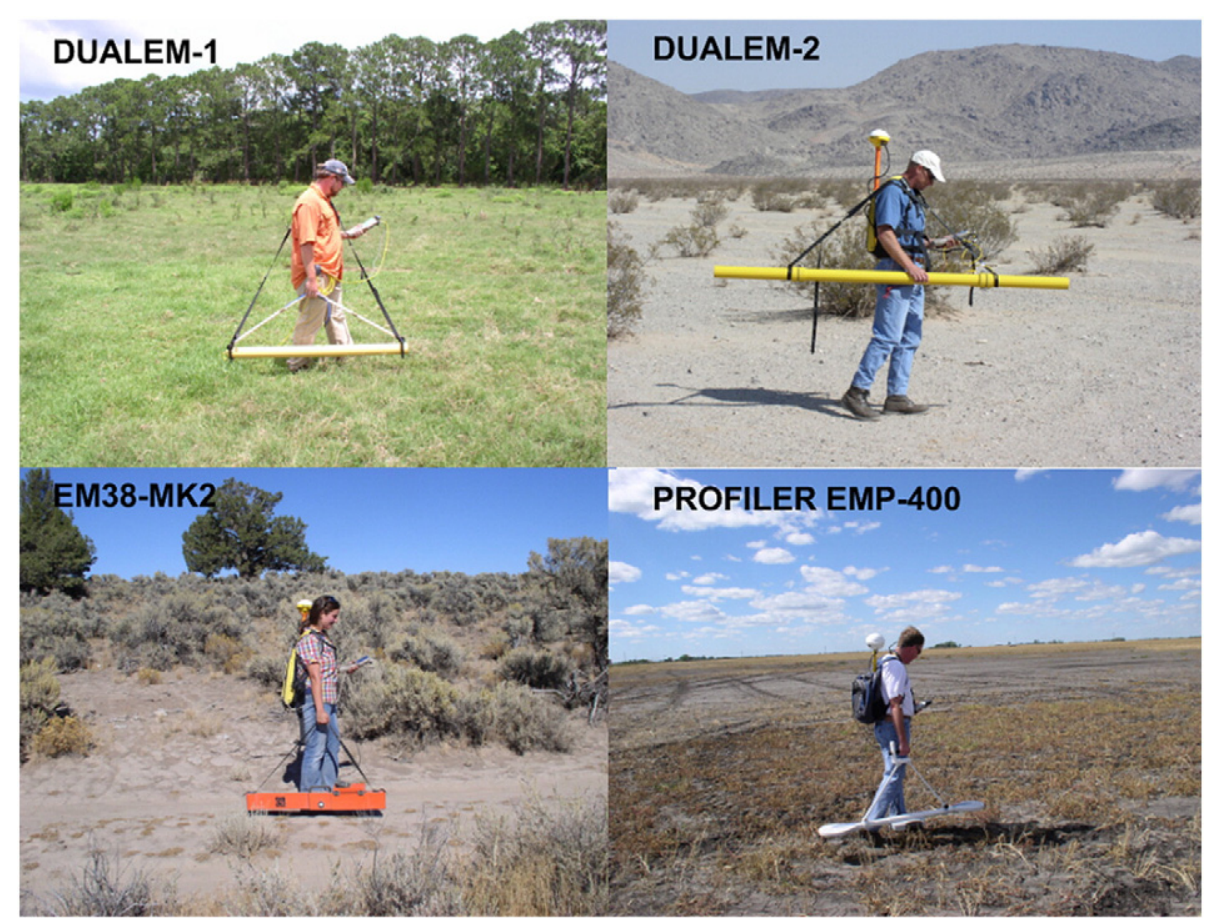

Fig. 1. Four EMI sensors commonly used in soil investigations are the DUALEM-1 meter, the DUALEM-2 meter, the EM38-MK2 meter, and the Profiler EMP-400.

Electromagnetic induction sensors measure changes in the apparent electrical conductivity $\left(\mathrm{EC}_{\mathrm{a}}\right)$ of the subsurface without direct contact with the sampled volume (Allred et al., 2008; Daniels et al., 2003). Apparent electrical conductivity is a depth-weighted, average conductivity measurement for a column of earthen materials to a specific depth (Greenhouse and Slaine, 1983). Variations in $\mathrm{EC}_{\mathrm{a}}$ are produced by changes in the electrical conductivity of earthen materials. Apparent electrical conductivity will increase with increases in soluble salt, water, clay contents, and temperature (Brevik and Fenton, 2002; Kachanoski et al., 1988; McNeill, 1980a; Rhoades et al., 1976).

\section{EMI sensors}

An increasing number of commercially available EMI sensors are available (Fig. 1). Electromagnetic induction sensors commonly used in agriculture and soil investigations include the DUALEM- 1 and DUALEM-2 meters (Dualem, Inc., Milton, Ontario); the EM31, EM38, EM38-DD, and EM38-MK2 meters (Geonics Limited, Mississauga, Ontario), and the Profiler EMP-400 (Geophysical Survey Systems, Inc., Salem, New Hampshire). ${ }^{1}$ These EMI sensors transmit a primary electromagnetic field, which induces electrical currents in the soil. These currents generate a secondary electromagnetic field, which is read by the sensor's receiver. Under conditions known as "operating under low induction numbers", the secondary field is proportional to the ground current and is used to calculate the "apparent" or "bulk" electrical conductivity $\left(\mathrm{EC}_{\mathrm{a}}\right)$ for the volume of soil profiled. The dual-geometry configuration of the DUALEM-1 and DUALEM-2 meters, the dual orientation of the EM38-DD meter, and the dual receiver-transmitter spacings of the EM38-MK2 meter allow the simultaneous measurement of $\mathrm{EC}_{\mathrm{a}}$ and/or apparent magnetic susceptibility (MSa) over two distinct depths. The depth of investigation (DOI) for $\mathrm{EC}_{\mathrm{a}}$ measurements made with sensors developed by Dualem, Inc. and Geonics Limited is commonly taken as the depth of 70\% cumulative response. The Profiler EMP-400 is a multi-frequency sensor and its DOI is assumed to be "skin-depth"

\footnotetext{
1 Manufacturer's names are provided for specific information; use does not constitute endorsement.
}

limited and dependent upon the frequency and the conductivity of the profiled materials. All of the aforementioned sensors support GPS communication, data loggers, and proprietary software. Some EMI sensors, such as the DUALEM-1, DUALEM-2S, and Profiler EMP-400, come with internal GPS receivers and display/keypads.

Each of the aforementioned sensors has distinct operational advantages and disadvantages (Sudduth et al., 2003). Comparative studies have generally revealed close similarities between $\mathrm{EC}_{\mathrm{a}}$ data collected with different sensors (Doolittle et al., 2001, 2002a; Saey et al., 2009a; Sudduth et al., 1999, 2003; Urdanoz and Aragüés, 2012). However, differences in sensor calibration, depth sensitivity and volume of soil material measured will affect measurements and result in slightly different $\mathrm{EC}_{\mathrm{a}}$ values. In comparative studies using different sensors, the highest correlations in measured $\mathrm{EC}_{\mathrm{a}}$ were obtained with sensors having similar depth sensitivities (Sudduth et al., 1999, 2003). Differences in $\mathrm{EC}_{\mathrm{a}}$ data collected with different sensors have been attributed to differences in sensing depths and data collection modes (e.g., coil spacing, orientation, or geometry). In general, differences in $\mathrm{EC}_{\mathrm{a}}$ data collected with different sensors have been more noticeable over soils with highly contrasting layers (Sudduth et al., 2003).

\section{History}

The first use of EMI in agriculture was for the assessment of soil salinity (Corwin and Rhoades, 1982; de Jong et al., 1979; Rhoades and Corwin, 1981; van der Lelij, 1983; Williams and Baker, 1982). In 1976, Geonics Limited patented and manufactured the EM31 meter. The EM31 meter has a $3.66 \mathrm{~m}$ intercoil spacing and operates at a frequency of $9.8 \mathrm{kHz}$ (Fig. 2). This meter provides DOI of $3 \mathrm{~m}$ and $6 \mathrm{~m}$ when operated in the horizontal (HDO) and vertical (VDO) dipole orientations, respectively. Consideration for near-surface applications in agronomy and soil science lead to the development of the EM38 meter in 1980. The EM38 meter is the most widely used EMI sensor in agriculture (Sudduth et al., 2001). The EM38 meter has a coil separation of $1 \mathrm{~m}$ and operates at a frequency $14.6 \mathrm{kHz}$. This meter provides DOI of 0.75 and $1.5 \mathrm{~m}$ when operated in the HDO and VDO, respectively. 


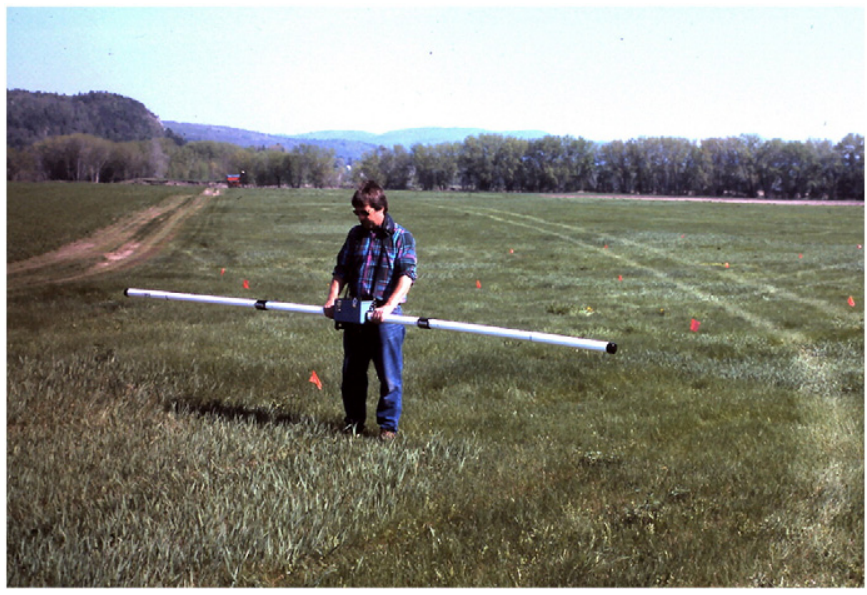

Fig. 2. In the 1980s, pedestrian surveys were typically completed with EMI sensors across gridded areas. Here, an EM31 meter is operated in the station-to-station mode without data logger (another person was required to record the data).

In the 1980s, EMI surveys were commonly completed in a station-tostation mode across gridded areas or along traverse lines. The establishment of a survey grid often took more time than the actual EMI survey. Pedestrian surveys were conducted by moving from one grid point to the next within the gridded area (Fig. 2). Typically, measurements were made in two dipole orientations at each grid intersection.

In the late1980s, data loggers were first used with EMI meters. Data could now be quickly and accurately recorded in the field and later transferred to computers for processing and display. By the mid- to late-1990s, the maturation of GPS and its integration with EMI sensors and data loggers revolutionized the collection of $\mathrm{EC}_{\mathrm{a}}$ data. The merger of these technologies allowed continuous sampling and made possible the rapid collection of geo-referenced EMI data using on-the-go or mobile platforms. This fusion of technologies allowed the rapid collection of spatially dense data sets and made intensive field-scale surveys practical and commonplace (Cannon et al., 1994; Carter et al., 1993; Freeland et al., 2002) (Fig. 3). However, when operated in the continuous recording mode, EMI sensors cannot be rotated back and forth between the two dipole orientations, and as a consequence, two separate surveys were required to collect data in both dipole orientations (two different depths). Many users wanted simultaneous measurements of EMI data in both dipole orientations to provide two DOI with one pass of the sensor. This led to the development of dual-dipole sensors, which

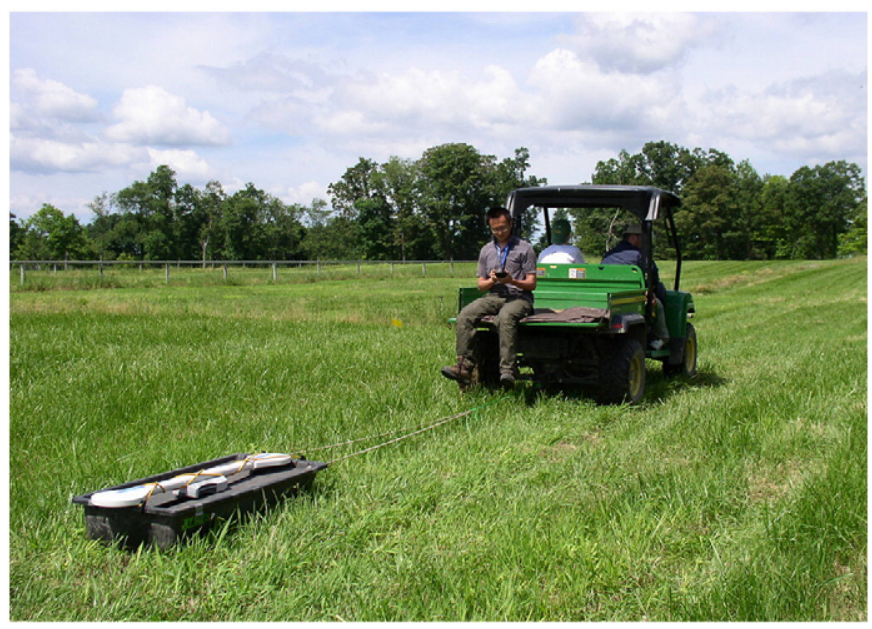

Fig. 3. The fusion of EMI and GPS technologies fostered the use of mobile EMI platforms, which facilitated the rapid collection of spatially dense data sets across large units of management. Here, a Profiler EMP-400 is being towed on sleds behind a 4WD allterrain-vehicle. permitted continuous, simultaneous measurements of $\mathrm{EC}_{\mathrm{a}}$ and/or MSa in two dipole configurations.

In 1998, Dualem developed the DUALEM-4 sensor with dual 4-m arrays that provide DOI of $2 \mathrm{~m}$ and $6 \mathrm{~m}$ in the perpendicular (PRP) and horizontal co-planar (HCP) geometry, respectfully. The PRP geometry is equivalent to HDO and the HCP geometry is equivalent to VDO as used in reference to the Geonics instruments. The DUALEM- 4 was followed by the DUALEM 42, which could be assembled with either 4$\mathrm{m}$ or $2-\mathrm{m}$ arrays. The DOI for the 2 meter array is $1 \mathrm{~m}$ and $3 \mathrm{~m}$ in the PRP and HCP geometry, respectfully. In 2004, Dualem introduced the DUALEM-1 and DUALEM-1S sensors that have 1-m arrays and provide DOI of $0.5 \mathrm{~m}$ and $1.5 \mathrm{~m}$ in the PRP and HCP geometry, respectfully. The first Dualem sensor with dual arrays of multiple lengths was the DUALEM-21, introduced in 2007. This EMI sensor was followed by the DUALEM-421 in 2008 and the DUALEM-642 in 2011. These complex EMI sensors incorporate six arrays, which provide six DOI. Each DUALEM sensor operates at a fixed frequency of $9.0 \mathrm{kHz}$ and provides simultaneous measurements of both $\mathrm{EC}_{\mathrm{a}}$ and MSa. These sensors come with internal WAAS-enabled GPS receivers and a hand-held weatherproof display/keypad.

In 2000, Geonics Limited developed the EM38-DD meter, which consists of two EM38 meters bolted together and electronically coupled. One unit is positioned in the VDO and one unit is positioned in the HDO to provide simultaneous measurements of $\mathrm{EC}_{\mathrm{a}}$ or MSa over two depth intervals. In 2008, Geonics Limited developed the EM38-MK2 meter, which operates at $14.6 \mathrm{kHz}$ and has one transmitter coil and two receiver coils that are separated from the transmitter coil at distances of 1.0 and $0.5 \mathrm{~m}$. This geometry results in DOI of 1.5 and $0.75 \mathrm{~m}$ when the meter is operated in the VDO, and 0.75 and $0.40 \mathrm{~m}$ when operated in the HDO. The EM38-MK2 meter provides simultaneous measurements of both $\mathrm{EC}_{\mathrm{a}}$ and MSa.

The Profiler EMP-400 is a multi-frequency electromagnetic induction sensor developed by Geophysical Survey System, Inc. in 2007. The system's primary data output is the in-phase and quadrature phase components of the mutual coupling field ratio of the transmitted field to the induced field in parts per million ( $\mathrm{ppm}$ ) at all frequencies, and $\mathrm{EC}_{\mathrm{a}}$ at $15 \mathrm{kHz}$. The Profiler can simultaneously collect both in-phase and quadrature phase component data at one to three frequencies. The Profiler has an intercoil spacing of $1.22 \mathrm{~m}$ and operates at frequencies of 1 to $16 \mathrm{kHz}$. The Profiler comes with an integrated GPS receiver and the sensor's electronics are controlled from a personal digital assistant (PDA) via a wireless Bluetooth communications interface.

Present EMI sensors are well suited to soil studies. The future will witness the expanded use of multiple-frequency and multiple-coil EMI sensors and various combinations of these instruments to more effectively assess the variability of soil properties (Triantafilis et al., 2013). The multiple depth responses of EMI sensors will be increasingly exploited with multi-layer inversion modeling algorithms to improve the resolution of subsurface features and the assessment of soil properties (Meerschman et al., 2011b; Mester et al., 2011; Saey et al., 2012a; Triantafilis and Monteiro Santos, 2013; Triantafilis et al., 2013). Multilayer inversion modeling of EMI data will advance the quantitative mapping of both the lateral and vertical variations in soil properties (Mester et al., 2011). As examples of this synergy, Saey et al. (2012b) and De Smedt et al. (2013a, 2013b) used multi-receiver EMI sensors and depth-slicing methods to improve the resolution of both archeological (drainage ditches) and pedological (soil horizons, stratigraphic layers, paleotopographical structures (paleochannels)) features.

\section{Applications}

\subsection{A surrogate measure for the assessment of soil properties}

Considerable research is being conducted to better understand the soil properties that influence $\mathrm{EC}_{\mathrm{a}}$. The principal properties affecting 
$\mathrm{EC}_{\mathrm{a}}$ are the type and concentration of ions in solution, the amount and type of clays in the soil matrix, the water content, and the temperature and phase of the soil water (McNeill, 1980a). Apparent conductivity has also been associated with other ancillary soil properties such as bulk density, soil structure, ionic composition, $\mathrm{CEC}, \mathrm{pH}$, and soil organic carbon, nutrient, and $\mathrm{CaCO}_{3}$ contents. These ancillary properties influence properties that determine soil $\mathrm{EC}_{\mathrm{a}}$, meaning they can indirectly influence $\mathrm{EC}_{\mathrm{a}}$ and thus be investigated using EMI techniques (Heilig et al., 2011). The relationships between these interacting soil properties and $\mathrm{EC}_{\mathrm{a}}$ are often complex and can vary over short distances (Bekele et al., 2005; Brevik and Fenton, 2004; Brevik et al., 2004; Carroll and Oliver, 2005; Farahani et al., 2005). As a result, the degree and in some cases the directions $( \pm)$ of the relationship between $\mathrm{EC}_{\mathrm{a}}$ and a specific soil property have varied. In general, stronger correlations are obtained where large differences in the measured soil property occur (horizontally and/or vertically), and all other soil properties that affect $\mathrm{EC}_{\mathrm{a}}$ remain relatively constant. Weaker correlations and lower predictive accuracies occur where the measured soil property displays low variability in relation to several other interacting and more variable soil properties that affect $\mathrm{EC}_{\mathrm{a}}$. Complex interactions among different soil properties can confound interpretations and create ambiguous, inconsistent, and less significant results. Even with these challenges, $\mathrm{EC}_{\mathrm{a}}$ has been increasingly used to infer and map the spatial variability of soil properties at field and landscape scales. Presently, $\mathrm{EC}_{\mathrm{a}}$ mapping is recognized as one of the most valuable methods in agriculture for measuring the spatial variability of soil properties at field and landscape scales (Corwin, 2008; Lück et al., 2009).

\subsubsection{Soil salinity}

As noted by Corwin (2008), the adaptation of EMI to agriculture was largely motivated by the need for reliable, quick, and easy to take measurements of soil salinity at field and landscape scales. In soil surveys, the identification and mapping of salt-affected soils have been traditionally made by visual observations supported by limited laboratory measurements (Soil Survey Division Staff, 1993; United States Salinity Laboratory Staff, 1954). Visual observations, though adequate for general salinity mapping, provide only qualitative information and are dependent on the presence of plant cover, surface salts, and soil structural features and characteristics. Laboratory methods (e.g., electrical conductivity of the saturated paste extract and the saturated solution extract; sodium absorption ratio, exchangeable sodium percentage) are time-consuming and expensive to complete, and provide only a limited number of point measurements that may or may not be representative of the field or soil-landscape. Because of the high spatial variability of salt-affected soils, these traditional methods, while reasonably accurate, have limited values for the assessments of soil salinity and sodicity at field and regional scales (Corwin, 2008). A major advantage of EMI is its capacity to produce a large number of georeferenced, quantitative measurements that can be associated with the spatial variability of salinity and sodicity at field and landscape scales.

In areas of salt-affected soils, of all the physiochemical properties that influence $\mathrm{EC}_{\mathrm{a}}$, the concentration of soluble salts is the dominant contributing factor (Johnston et al., 1997; Mankin and Karthikeyan, 2002; van der Lelij, 1983; Williams et al., 2006). In these areas, EMI has been used to characterize unsaturated flow (Scanlon et al., 1999), estimate rates of groundwater recharge (Cook et al., 1989a, 1989b, 1992), map groundwater recharge and discharge zones (Richardson and Williams, 1994; Williams et al., 2006), and assess differences in soluble salt contents across landscapes (Cook et al., 1989a; Williams et al., 2006). Studies have confirmed that EMI provides reasonably accurate estimates of soil salinity at field scales (Diaz and Herrero, 1992; van der Lelij, 1983; Williams and Baker, 1982).

Early EMI research and field services in the late 1970s and early 1980 s were principally directed towards the vertical profiling of salinity through the root zone (Corwin, 2008). A major challenge in using EMI to map soil salinity has been the conversion of apparent conductivity
$\left(E C_{a}\right)$ into the conductivity of the saturated paste extract $\left(E C_{e}\right)$; the most commonly used measure of soil salinity. A number of models were developed to predict $\mathrm{EC}_{\mathrm{e}}$ from $\mathrm{EC}_{\mathrm{a}}$ (Cook and Walker, 1992; Corwin and Rhoades, 1982, 1984, 1990; Johnston et al., 1997; Lesch et al., 1992, 1995a, 1995b; McKenzie et al., 1989; Rhoades et al., 1989a, 1989b; Slavich, 1990; Wollenhaupt et al., 1986). Unfortunately, models are imperfect and tend to be both time dependent and site specific (Lesch et al., 1998). As a consequence, calibration equations and modeled results usually cannot be extrapolated to other sites (Cassel et al., 2009). Another challenge to the use of EMI to map salinity occurs at high conductivity values, when the quadrature component of the received electromagnetic field is no longer linearly proportional to soil conductivity (breakdown of low induction number approximation); this occurs above conductivities of approximately $100 \mathrm{mS} \mathrm{m}^{-1}$ (McNeill, 1980b; Morris, 2009).

\subsubsection{Subsurface water movement and soluble salts}

The depth and movement of water through the subsurface have a direct effect on the physical and chemical properties and the morphology of soils (Richardson et al., 1992). Recharge processes remove soluble chemical constituents and translocate suspended colloids in soils. Discharge processes add soluble chemical constituents and suspended colloids to soils (Richardson et al., 1992). Because of upward leaching and evaporative processes, salts are concentrated near the soil surface in groundwater discharge sites (seeps) (Richardson and Williams, 1994). The higher concentration of soluble salts in surface layers results in higher $\mathrm{EC}_{\mathrm{a}}$ and inverted salt profiles ( $\mathrm{EC}_{\mathrm{a}}$ is highest in surface layers and decreases with increasing depth). Conversely, groundwater recharge sites are characterized by the downward leaching and concentration of salts at greater soil depths. As a consequence, $\mathrm{EC}_{\mathrm{a}}$ is relatively low in surface layers and increases with increasing depth (regular salt profile). In recharge areas, lower soluble salt and water contents are associated with lower $\mathrm{EC}_{\mathrm{a}}$ (Mankin and Karthikeyan, 2002).

The aforementioned relationships have been used to map saline- and sodic-soils (Ammons et al., 1989; Doolittle et al., 2001; Ganjegunte and Braun, 2011; Heilig et al., 2011; Lesch et al., 1992; Nettleton et al., 1994; Thomas et al., 2009) and recharge and discharge areas (Hopkins and Richardson, 1999; Sherlock and McDonnell, 2003; Williams and Arunin, 1990). Fig. 4 shows spatial EC and interpreted salinity and sodicity data from a 1.5 ha field located in the Rolling Soft Shale Plain of southwestern North Dakota. ${ }^{2}$ Within this site, soils are mapped as Janesburg-Dogtooth silt loams, 0 to $6 \%$ slopes. The moderately deep, well drained, Janesburg soils (fine, smectitic, frigid Typic Natrustolls) and the deep and very deep, moderately well and well drained Daglum soils (fine, smectitic, frigid Vertic Natrustolls) formed in clayey residuum. In Fig. 4, the plots on the left show the $\mathrm{EC}_{\mathrm{a}}$ measured for two depth intervals with an EM38-MK2 meter. As evident in these plots, $\mathrm{EC}_{\mathrm{a}}$ increases with increasing depth. The points shown on these plots are the sampling points identified and located using the ESAP software suite (Lesch et al., 2000). Based on limited sampling and stochastic equations contained in the ESAP program, levels of salinity and sodicity were predicted for each of the $1682 \mathrm{EC}_{\mathrm{a}}$ measurement points within this field. The presence of natric horizons and sodicity is recognized in the taxonomic classification and mapping of these soils. However, as shown in the right-hand plot of Fig. 4, for the 0 to $90 \mathrm{~cm}$ depth interval, saline non-sodic and saline-sodic conditions dominate (78\%) this area, while non-saline and non-sodic soil conditions make up $22 \%$ of the site. The presence of these conditions should be recognized in this soil map unit.

Fig. 5 shows the spatial variability of EC $_{\mathrm{a}}$ across a 65 ha field that contains saline seeps in the Brown Glaciated Plain of north central Montana (Doolittle, 2013). In Fig. 5, the saline seeps are identified by their high $\mathrm{EC}_{\mathrm{a}}(>150 \mathrm{mS} / \mathrm{m})$. These seeps appear to be arranged in a discontinuous, sinuous pattern that meanders across the field from

\footnotetext{
2 Names for all Major Land Resource Areas taken from United States Department of Agriculture, Natural Resources Conservation Service (2006).
} 

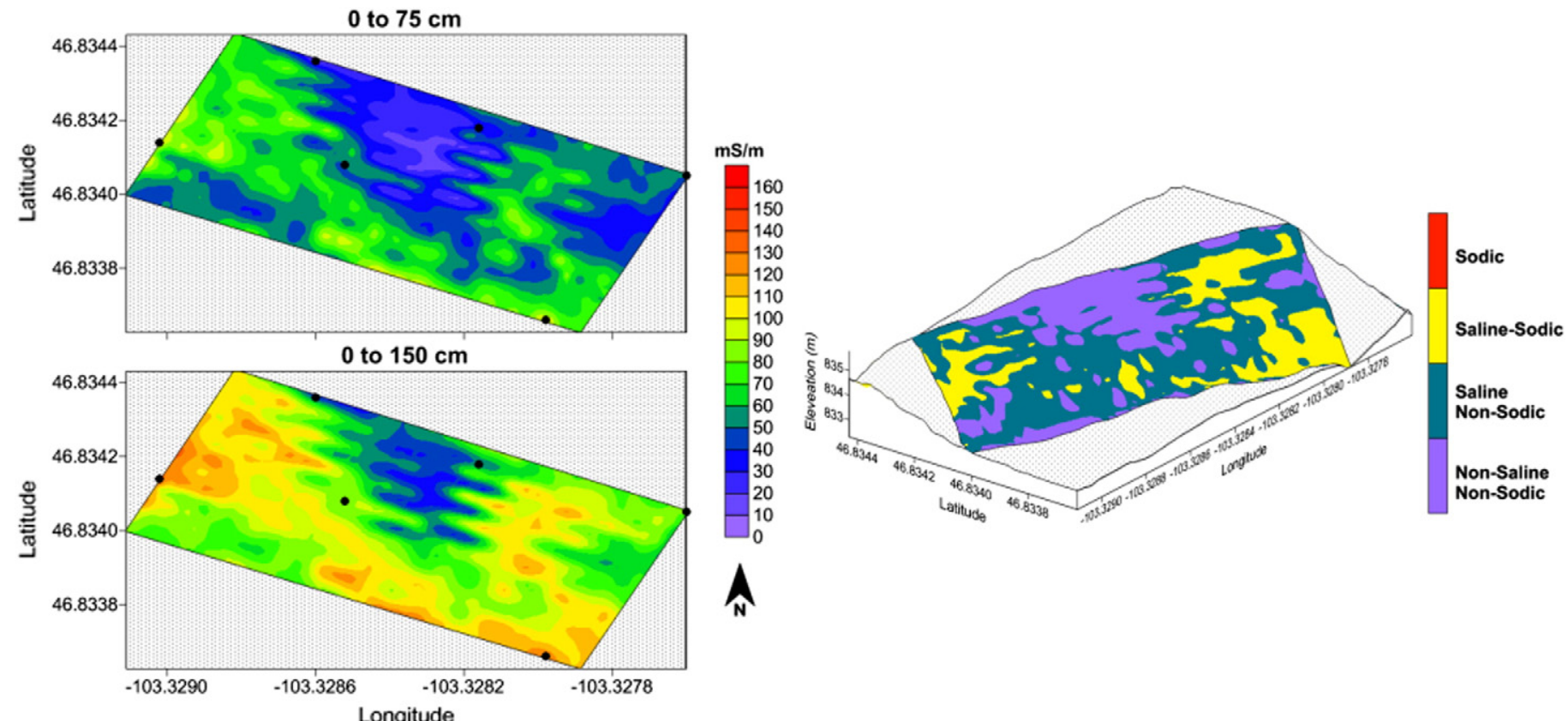

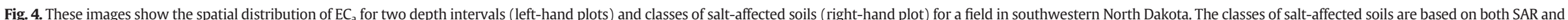
soil salinity levels for the 0 to $90 \mathrm{~cm}$ soil column as predicted by stochastic models of $\mathrm{EC}_{\mathrm{a}}$ (Heilig et al., 2011). 


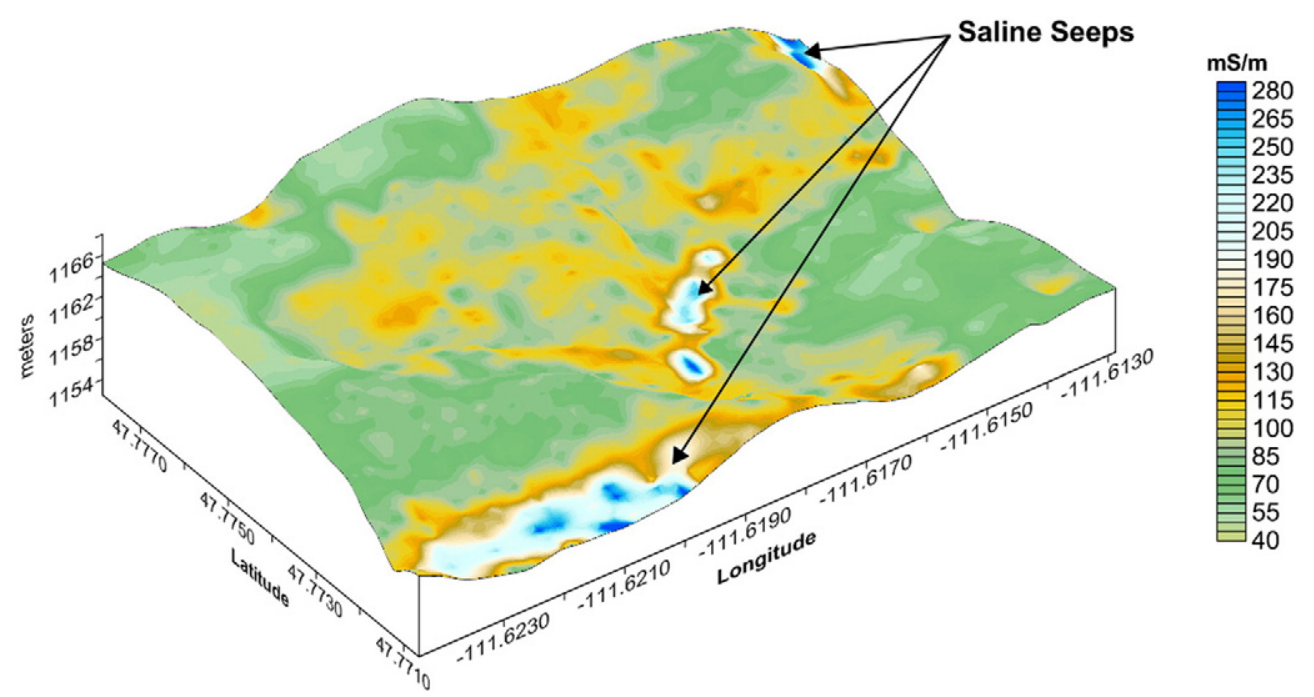

Fig. 5. This 3D simulation shows the spatial distribution of $\mathrm{EC}_{\mathrm{a}}$ and the locations of saline seeps within an area of dryland farming in north central Montana (Doolittle, 2013).

the southwest to the northeast corner. Also evident on this plot are lines of moderate $\mathrm{EC}_{\mathrm{a}}$ values that extend in a west-northwesterly and upslope direction away from these seeps. These delineations are believed to represent potential subsurface flow paths that have relatively higher concentrations of soluble salts. These lines may represent preferential channels for excess water to drain from recharge areas (located on higher-lying areas to the west and north). In Fig. 5, suspected recharge areas have relatively low $\mathrm{EC}_{\mathrm{a}}$ values.

\subsubsection{Other soil properties}

Apparent conductivity has also been used as a surrogate measure of soil water content (Allred et al., 2005; Brevik et al., 2006; Hezarjaribi and Sourell, 2007; Huth and Poulton, 2007; Kachanoski et al., 1988, 1990; Khakural et al., 1998; Korsaeth et al., 2008; Mueller et al., 2003; Sheets and Hendrickx, 1995; Tromp-van Meerveld and McDonnell, 2009; Waine et al., 2000), soil texture (Heil and Schmidhalter, 2012; James et al., 2003; Saey et al., 2012a; White et al., 2012); and clay content (Cockx et al., 2009; Harvey and Morgan, 2009; King et al., 2005; Mueller et al., 2003; Sommer et al., 2003; Weller et al., 2007; Wienhold and Doran, 2008; Williams and Hoey, 1987). Electromagnetic induction has been used to assess difference in lithology and mineralogy (Bourgault and Rabenhorst, 2012; Doolittle et al., 2005, 2013), soil compaction (Al-Gaadi, 2012; Brevik and Fenton, 2004; Sudduth et al., 2010); CEC (Korsaeth et al., 2008; Triantafilis et al., 2009;), exchangeable Ca and Mg (McBride et al., 1990), $\mathrm{CaCO}_{3}$ (Vitharana et al., 2008b); soil pH (Bianchini and Mallarino, 2002; Dunn and Beecher, 2007; Van Meirvenne et al., 2013; Vitharana et al., 2008b; Wienhold and Doran, 2008), soil organic carbon (Jaynes, 1996b; Johnson et al., 2001; Korsaeth et al., 2008; Martinez et al., 2009; Vitharana et al., 2008b), field-scale leaching rates of solutes (Slavich and Yang, 1990), herbicide partition coefficients (Jaynes et al., 1994), and available N (Eigenberg et al., 2002; Wienhold and Doran, 2008). In these studies, $\mathrm{EC}_{\mathrm{a}}$ was either directly related to a soil property or the property (such as soil organic carbon) was associated with changes in a property (e.g., moisture and/or clay content) that affects $\mathrm{EC}_{\mathrm{a}}$.

\subsection{Refine and improve the quality of soil maps}

Electromagnetic induction has been increasingly used to support soil surveys and site-specific management (Brevik, 2012). At field and landscape scales, $\mathrm{EC}_{\mathrm{a}}$ maps have the potential to provide higher levels of resolution and greater distinction of soil types than soil maps prepared with traditional tools and survey methods provided there is significant variation in at least one of the factors that affects soil $\mathrm{EC}_{\mathrm{a}}$ (James et al.,
2003; Jaynes, 1995, 1996a; Shaner et al., 2008). However, EC $\mathrm{a}_{\mathrm{a}}$ surveys can also be used to confirm highly uniform soil properties throughout a field (Brevik et al., 2012).

Interpretations of $\mathrm{EC}_{\mathrm{a}}$ maps are based on the identification of spatial patterns within data sets. Though seldom diagnostic in themselves, lateral and vertical variations in $\mathrm{EC}_{\mathrm{a}}$ are used to infer changes in soil types and properties (Corwin, 2008; Daniels et al., 2003; Doolittle et al., 1994, 1996; Jaynes et al., 1993; Kravchenko et al., 2002; Sudduth et al., 1995). The effectiveness of EMI as a soil mapping tool will depend upon the degree to which differences in the physical and chemical properties that affect $\mathrm{EC}_{\mathrm{a}}$ correspond to differences in soils. Where strong and meaningful relationships can be established between soils and $\mathrm{EC}_{\mathrm{a}}$, field-scale $\mathrm{EC}_{\mathrm{a}}$ mapping has been used to identify areas of reasonably homogenous soils and soil properties (Doolittle et al., 1996; Frogbrook and Oliver, 2007; Johnson et al., 2001), and to improve existing soil maps (Doolittle et al., 2008; Hedley et al., 2004; Vitharana et al., 2008a). A major contribution of EMI surveys has been the identification and delineation of small included areas of dissimilar soils within soil polygons that have been mapped on second-order soil maps (Fenton and Lauterbach, 1999), although some common EMI sampling methods tend to represent soils that occupy a large percentage of the area within a field more representatively than soils that occupy small areas (Brevik, 2012).

In many areas, spatial $\mathrm{EC}_{\mathrm{a}}$ patterns correspond well with soil patterns shown on soil maps. Fig. $6 \mathrm{a}$ and b show high-intensity $\mathrm{EC}_{\mathrm{a}}$ maps for two fields located within the Mississippi Alluvial Plain of southeastern Missouri. These maps were prepared from measurements made with an EM38 meter operated in the VDO (DOI of $1.5 \mathrm{~m}$ ). On each map, soil names and map unit boundary lines have been imported from the Web Soil Survey. ${ }^{3}$ Although the same color ramp has been used, differences in scales make the $\mathrm{EC}_{\mathrm{a}}$ not directly comparable between these maps.

Each of the surveyed fields shown in Fig. 6a and b has been landleveled and agricultural drainage pipes have been installed to improve soil drainage and crop yields. The taxonomic classifications of the soils identified in these fields are listed in Table 1. Soil-landform relationships, which were once more obvious in these landscapes, have been obscured by land leveling. Land leveling has not only disturbed the soils, but has eliminated many "topographic breaks" that are used by soil scientists to identify soil boundaries and map soils using soil-

\footnotetext{
3 Soil Survey Staff, Natural Resources Conservation Service, United States Department of Agriculture. Web Soil Survey. Available online at http://websoilsurvey.nrcs.usda.gov/. Accessed [08/28/2013].
} 

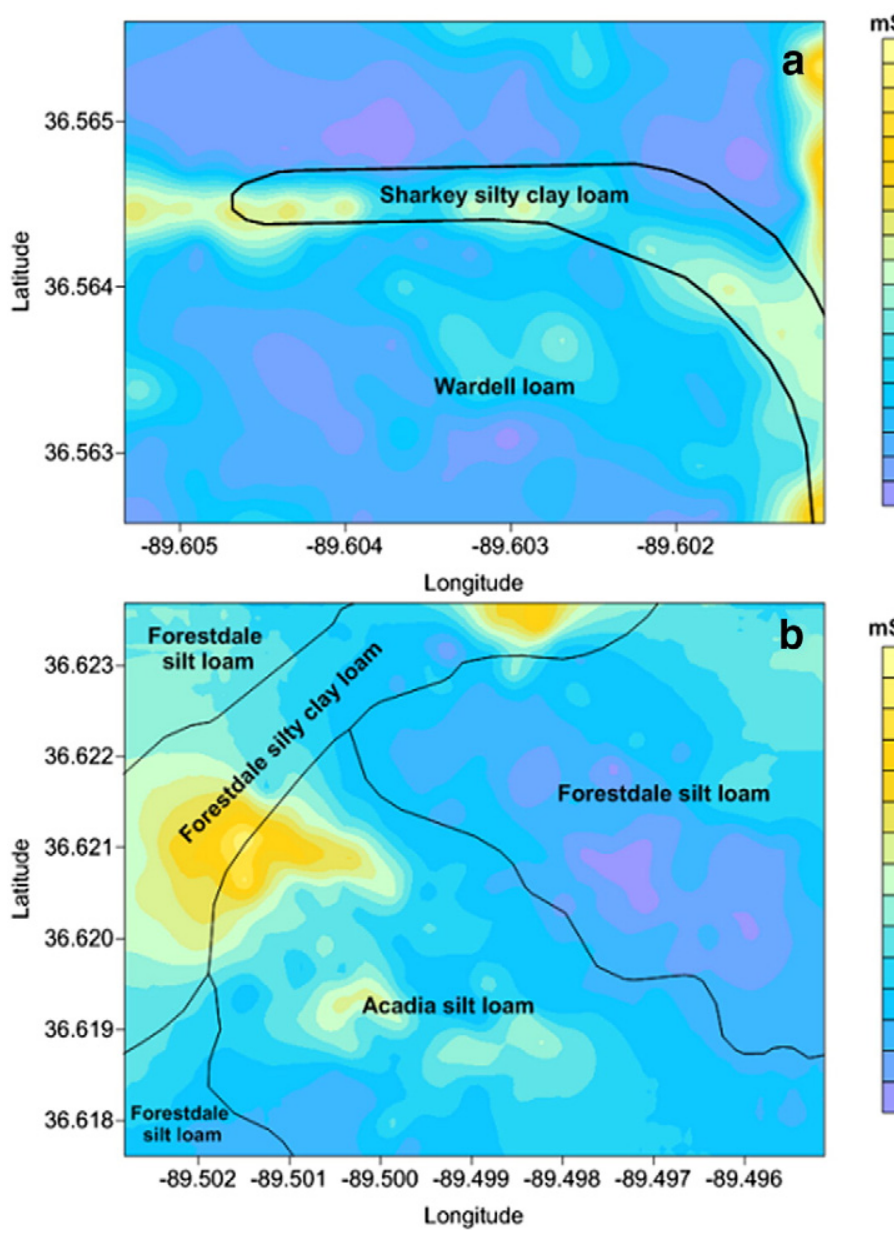
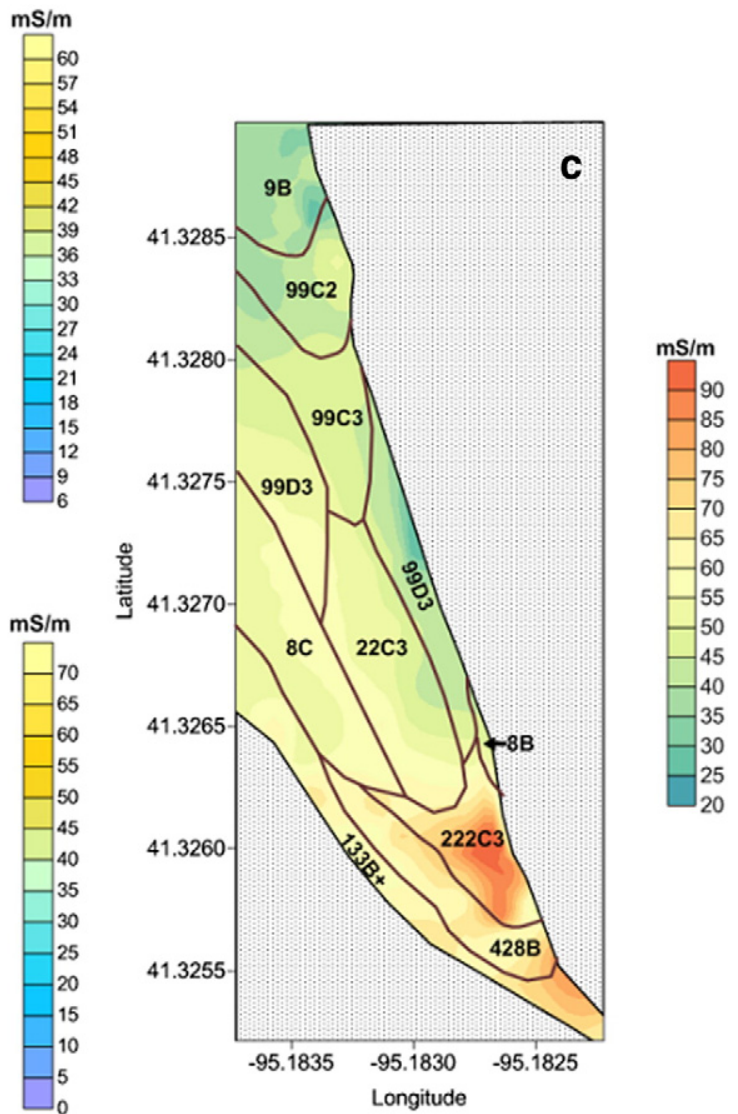

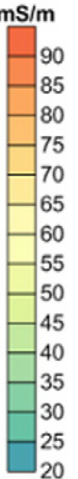

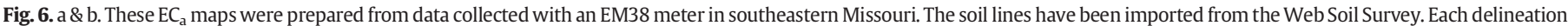

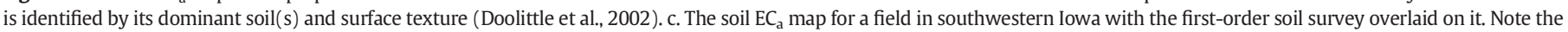
high $\mathrm{EC}_{\mathrm{a}}$ values in the area mapped as Clarinda (222C3), a paleosol-derived soil that can have as much as 60\% clay in the upper $1.5 \mathrm{~m}$ (Brevik and Fenton, 2003).

landform relationships. Lacking noticeable slope breaks, the task of identifying and mapping the soils would be more time-consuming and laborious using traditional soil mapping field procedures (Brevik and Fenton, 1999) than with EMI.

Soils with higher clay contents have higher $\mathrm{EC}_{\mathrm{a}}$. In Fig. 6a and b, areas of clayey Arcadia, Forestdale, and Sharkey soils have the highest $\mathrm{EC}_{\mathrm{a}}$ $(>35 \mathrm{mS} / \mathrm{m})$. In Fig. 6b, included areas of Wiville soils have the lowest $\mathrm{EC}_{\mathrm{a}}(<6 \mathrm{mS} / \mathrm{m})$. The Wiville soils formed on former dunes, and have lower clay contents and sandy $\mathrm{C}$ horizons. These former dunes are no longer present on this land-leveled field and relatively extensive areas of Wiville soil were over looked in mapping. In Fig. 6a, areas of Wardell soils have intermediate clay contents and $\mathrm{EC}_{\mathrm{a}}$.

The delineation of soils with paleosol parent materials can be important for agricultural management in the Deep Loess Hills of southwestern Iowa due to the high clay-content of these soils. However, it is not always easy to pick out small areas of such soils during field mapping. Brevik and Fenton (2003) investigated the use of the EM38 to identify paleosol-derived soils and compared the $\mathrm{EC}_{\mathrm{a}}$ patterns to first-order

Table 1

Taxonomic classification of soils identified in Fig. $6 a$ and b.

\begin{tabular}{ll}
\hline Soil series & Taxonomic classification \\
\hline Arcadia & Fine, smectitic, thermic Aerie Epiaqualfs \\
Forestdale & Fine, smectitic, thermic Typic Endoaqualfs \\
Sharkey & Very-fine, smectitic, thermic Chromic Epiaquerts \\
Tuckerman & Fine-loamy, mixed, active, thermic Typic Endoaqualfs \\
Wardell & Fine-loamy, mixed, superactive, thermic Mollic Epiaqualfs \\
Wiville & Fine-loamy, siliceous, active, thermic Ultic Hapludalfs
\end{tabular}

soil surveys that had been prepared for several fields in southwestern Iowa. One of the resulting maps is shown in Fig. 6c. In this example, the EM38 did a good job of differentiating between paleosol-derived and other soils, with the paleosol-derived soils often having $\mathrm{EC}_{\mathrm{a}}$ values in excess of $80 \mathrm{mS} / \mathrm{m}$ while other soils in these fields rarely exceeded $70 \mathrm{mS} / \mathrm{m}$ (92\% of the $\mathrm{EC}_{\mathrm{a}}$ readings were $70 \mathrm{mS} / \mathrm{m}$ or less). Taxonomic classification information for the dominant soils in the Iowa field is given in Table 2.

In Fig. 6c, the delineation of Clarinda soils (222C2) has clay contents of as much as $60 \%$ in the upper $1.5 \mathrm{~m}$ of the profile. The paleosol-derived Clarinda soil clearly stands out from the courser-textured soils around it.

On each of the maps shown in Fig. 6, spatial $\mathrm{EC}_{\mathrm{a}}$ patterns conform to the general soil patterns of the first- or second-order soil survey.

Table 2

Taxonomic classification of soils identified in Fig. 6c.

\begin{tabular}{|c|c|c|}
\hline $\begin{array}{l}\text { Soil } \\
\text { series }\end{array}$ & $\begin{array}{l}\text { Soil map } \\
\text { unit(s) }\end{array}$ & Taxonomic classification \\
\hline Judson & $8 \mathrm{~B}$ and $\mathrm{C}$ & Fine-silty, mixed, superactive, mesic Cumulic Hapludolls \\
\hline Marshall & 9B & Fine-silty, mixed, superactive, mesic Typic Hapludolls \\
\hline Dow & $22 \mathrm{C} 2$ & $\begin{array}{l}\text { Fine-silty, mixed, superactive, calcareous, } \\
\text { mesic Typic Udorthents }\end{array}$ \\
\hline Exira & $\begin{array}{l}99 \mathrm{C} 2, \mathrm{C} 3 \\
\text { and } \mathrm{D} 2\end{array}$ & Fine-silty, mixed, superactive, mesic Typic Hapludolls \\
\hline Colo & 133B & Fine-silty, mixed, superactive, mesic Cumulic Endoaquolls \\
\hline Clarinda & $222 \mathrm{C} 2$ & Fine, smectitic, mesic Vertic Argiaquolls \\
\hline Ely & 428B & $\begin{array}{l}\text { Fine-silty, mixed, superactive, } \\
\text { mesic Aquic Cumulic Hapludolls }\end{array}$ \\
\hline
\end{tabular}




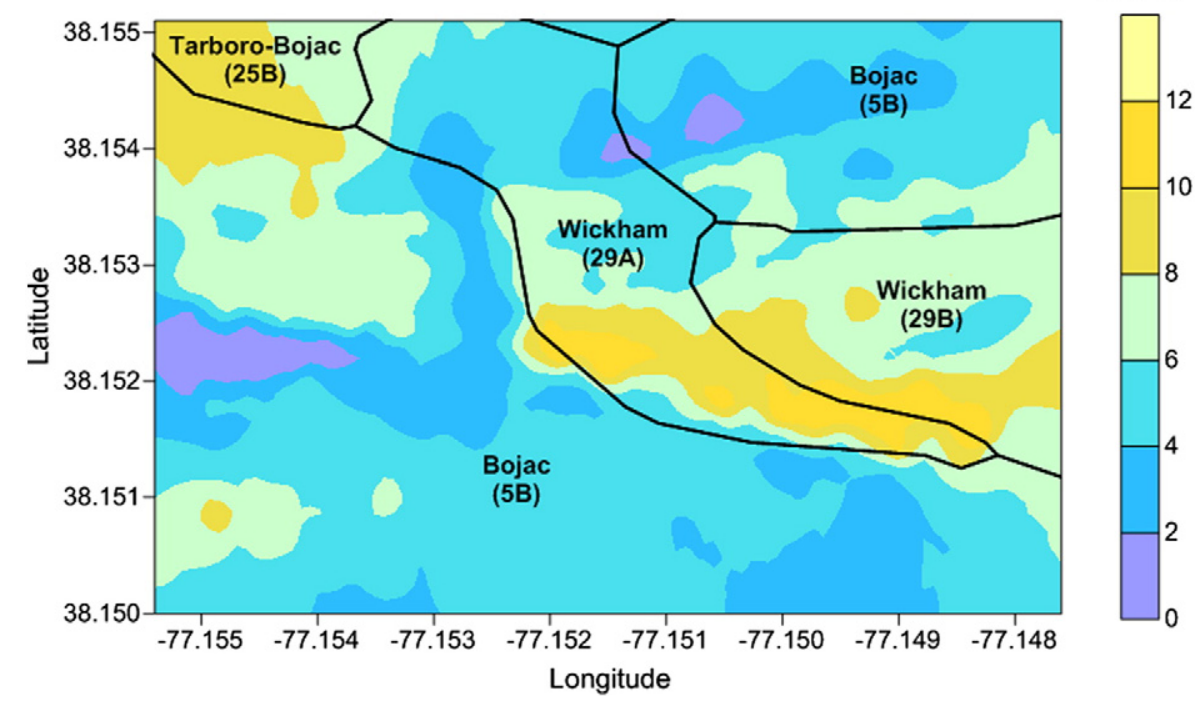

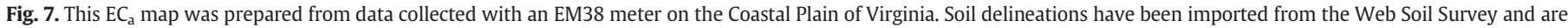
identified by their dominant soil(s) and map unit symbol (Anderson-Cook et al., 2002).

However, the more intensive EMI sampling has resulted in more intricate patterns and the depiction of greater spatial variability than displayed by the imported soil boundary lines alone. In these soil-landscapes spatial $\mathrm{EC}_{\mathrm{a}}$ patterns are principally associated with differences in clay content. In the Missouri fields, the correlation between $\mathrm{EC}_{\mathrm{a}}$ and clay content at different soil depths ranged from 0.545 to 0.903 (Doolittle et al., 2002a); while in the Iowa field, soils with the highest clay content as well as the highest smectite clay mineral content displayed the highest $\mathrm{EC}_{\mathrm{a}}$ values.

Soil variability and the transition from one soil type to another are well expressed on the soil EC $\mathrm{E}_{\mathrm{a}}$ maps shown in Fig. 6. The imported map unit boundary lines have a fixed width and cannot accurately portray the spatial rate of change in soils and soil properties. This can result in prediction errors, especially in areas where fairly broad transitional zones exist. As evident on the maps shown in Fig. 6, spatial $\mathrm{EC}_{\mathrm{a}}$ data can be used to improve the placement and representation of soil boundaries (Adamchuk et al., 2004; Greve and Greve, 2004; James et al., 2003). On these maps, the spatial rates of change in $\mathrm{EC}_{\mathrm{a}}$ provide measures of transition zone widths and improve the precision of map unit positioning and the representation of soil variability (Greve and Greve, 2004; Kweon, 2012).

Though widely used in site-specific management, the use of EMI by state and federal agencies to create or refine soil maps has been very limited (Kitchen et al., 1998). However, in several documented studies, $\mathrm{EC}_{\mathrm{a}}$ data were used to improve the quality of second-order soil maps (Harvey and Morgan, 2009; Lobell et al., 2010; Vitharana et al., 2008a). In addition, Saey et al. (2009b) prepared an $\mathrm{EC}_{\mathrm{a}}$ map of Belgium's East Flanders province $\left(3000 \mathrm{~km}^{2}\right.$ ) that was based on 4887 topsoil samples. This map has been useful in evaluating field-measured $\mathrm{EC}_{\mathrm{a}}$ patterns and measurements.

High-intensity or first-order soil mapping based on EMI is offered commercially in many countries to provide information on the distribution and variability of soils at field and landscape scales (Brevik and Fenton, 2003; Khakural et al., 1998; King et al., 2005; Korsaeth et al., 2008; Kravchenko, 2008; Weller et al., 2007). Recently, EMI has also been used to improve the quality of several first-order soil maps (Anderson-Cook et al., 2002; Doolittle et al., 2008, 2009; Farahani and Flynn, 2007; White et al., 2012). White et al. (2012) and Doolittle et al. (2008, 2009) used EC data with geographical information system (GIS) to improve first-order soil maps that were constructed using traditional methods on the Gulf Coastal Plain of Alabama and the Till Plains Section of Illinois, respectively. In both physiographic areas, soil maps prepared with EMI and conventional, high-intensity soil survey methods produced similar results. In these studies, a significant contribution of spatial $\mathrm{EC}_{\mathrm{a}}$ data was the increased confidence of soil scientists in their mapping decisions. The information provided by $\mathrm{EC}_{\mathrm{a}}$ maps led soil scientists to reevaluate soil mapping decisions and conceptual soil landscape models, recognize different soils, and modify soil maps.

Anderson-Cook et al. (2002) used $\mathrm{EC}_{\mathrm{a}}$ to distinguish soil types and significant differences in subsoil texture in an area dominated by very deep, well drained Bojac (coarse-loamy, mixed, semiactive, thermic Typic Hapludults) and Wickham (fine-loamy, mixed, semiactive, thermic Typic Hapludults) soils on the Atlantic Coastal Plain of Virginia (Fig. 7). Using the $\mathrm{EC}_{\mathrm{a}}$ data, Anderson-Cook et al. (2002) were able to correctly classify the soil type with an accuracy of greater than $85 \%$. Fig. 7 shows the distribution of $\mathrm{EC}_{\mathrm{a}}$ across this study site in relationship to the second-order soil map, which was prepared using traditional soil survey methods. Compared with the second-order soil map, the $\mathrm{EC}_{\mathrm{a}}$ map shows greater variability and more intricate spatial patterns.

In several field-scale and landscape-scale special soil research projects, EMI has been used to map small areas and assess the depths to argillic horizons, claypans, fragipans, hardpans, and petrocalcic horizons (Boettinger et al., 1997; Chen et al., 2000; Doolittle et al., 1994; Mueller et al., 2003; Saey et al., 2012a; Stroh et al., 1993; Sudduth and Kitchen, 1993; Sudduth et al., 1995, 2009), reconstruct buried landscapes (De Smedt et al., 2013a, 2013b; Saey et al., 2008, 2013) and periglacial features (Meerschman et al., 2011a, Saey et al., 2012a); estimate depths to bedrock (Bork et al., 1998; Doolittle et al., 1998, 2002b; Palacky and Stephens, 1990; Zalasiewicz et al., 1985), and assess differences in soil drainage (Kravchenko et al., 2002).

\subsection{A tool for soil-hydrologic studies}

Soil-hydrology relationships vary across landscapes and are often exceedingly complex. Characterizing these complex relationships at different spatial-temporal scales and assessing their impacts on subsurface flow and transport is a major challenge to hydrologic modelers. Soil-hydrology-landscape relationships have been traditionally measured and inferred from point-based pedologic observations. Point-sampling methods (such as soil pits, monitoring wells, core samples, and soil moisture probes) provide detailed, but highly site-specific soil and hydrologic data. As the collection of point data is timeconsuming, labor-intensive, costly, and generally destructive (Brevik 

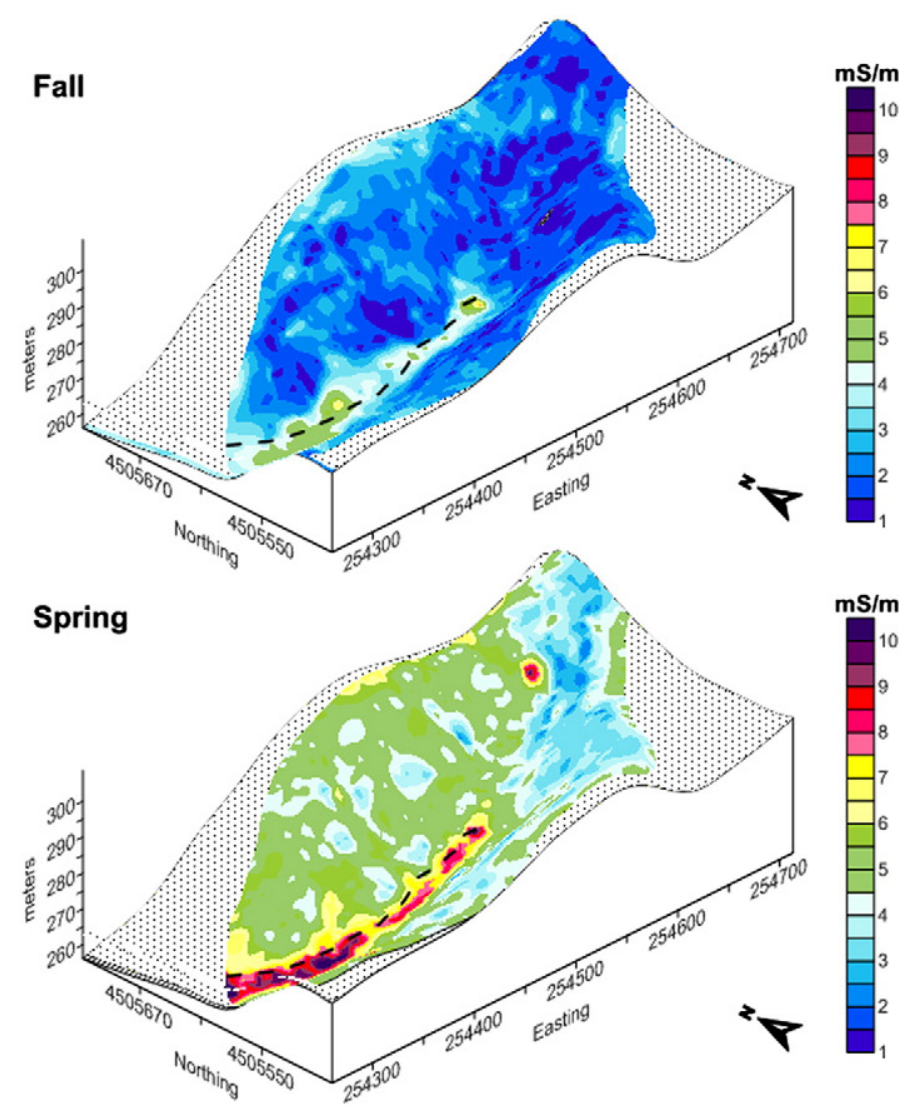

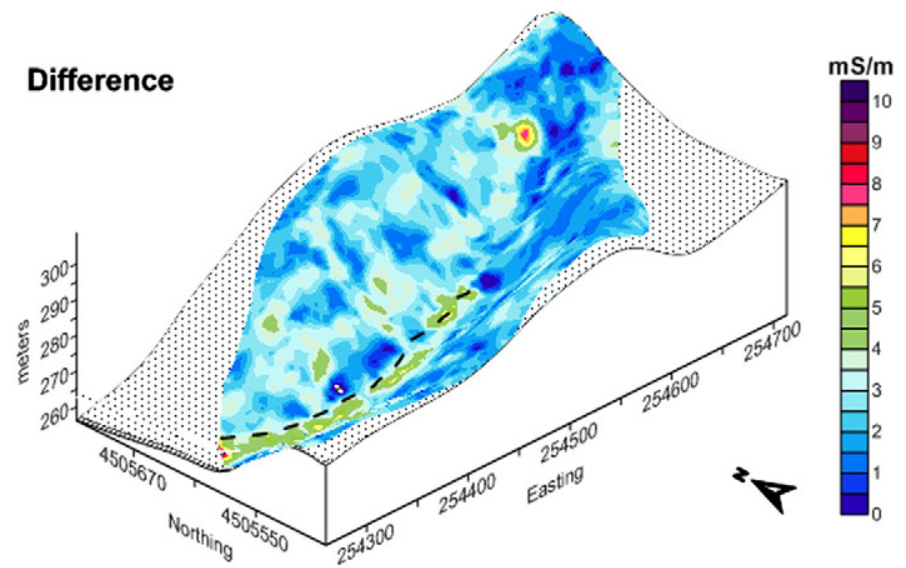

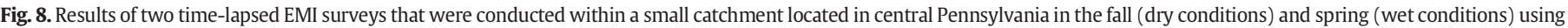
an EM38 meter with a density of about 750 measurements per ha (Doolittle et al., 2012).

and Batten, 2012; Brevik et al., 2003; Zhu et al., 2013), it is confined to a limited number of sampling points. Because of these limitations, soil and hydrologic properties and processes for the larger areas among the widely-spaced sampling points must be inferred.

Electromagnetic induction has been effectively used to reveal the complexity of soil-landscape architectures and their impact on subsurface flow at field, hillslope, and catchment scales, and to fill in data gaps caused by the limitations of point-sampling methods (Doolittle et al., 2012; Zhu et al., 2010a, 2010b). In hydropedological studies, EMI has been used to indirectly measure and characterize soil water content, subsurface flow, depth to water table, and soil drainage classes (Allred et al., 2005; Doolittle et al., 2000; Kachanoski et al., 1990; Khakural et al., 1998; Kravchenko et al., 2002; Robinson et al., 2008; Scanlon et al., 1999; Schumann and Zaman, 2003; Sheets and Hendrickx, 1995; Williams et al., 2006; Zhu et al., 2010a, 2010b). Studies have revealed that the relative difference in soil $\mathrm{EC}_{\mathrm{a}}$ across most landscapes remained relatively stable over time (Brevik et al., 2006; Zhu et al., 2010a). These relatively stable spatial $\mathrm{EC}_{\mathrm{a}}$ patterns correspond to soil-landform units. In addition, changes in the magnitude and spatial extent of $\mathrm{EC}_{\mathrm{a}}$ patterns over seasons within the same landscape indicated active zones of subsurface flow, which corresponded with simulated water flow paths and observed soil morphology.

In a study of a small (7.9-ha) catchment located in the Northern Appalachian Ridges and Valleys of central Pennsylvania, $\mathrm{EC}_{\mathrm{a}}$ data were collected under relatively dry (fall) and wet (spring) conditions (Doolittle et al., 2012). The catchment is incised into a ridge composed of thinly bedded, highly fractured, and folded acid shale. Seven welldefined, linear swales of varying dimensions extend down slope and onto the valley floor; five along the south-facing slopes, and two along the north-facing slopes. Soils are dominantly shallow $(0$ to $51 \mathrm{~cm})$ and moderately deep (51 to $102 \mathrm{~cm}$ ) to bedrock on side slopes and summit areas. However, soils are very deep $(>152 \mathrm{~cm})$ along the valley floor.
The catchment is characterized by exceedingly low and relatively invariable $\mathrm{EC}_{\mathrm{a}}$ (Fig. 8). Within this catchment, the very low $\mathrm{EC}_{\mathrm{a}}$ reflects the electrically resistive nature of the soil and bedrock, and the low ionic concentration of the soil solution. Reconnaissance EMI surveys conducted in fall and spring months revealed that $\mathrm{EC}_{\mathrm{a}}$ ranged from about 0 to $24 \mathrm{mS} / \mathrm{m}$. However, over most of the catchment, $\mathrm{EC}_{\mathrm{a}}$ did not vary by more than $4 \mathrm{mS} / \mathrm{m}$. In spite of the low and relatively invariable $\mathrm{EC}_{\mathrm{a}}$, temporal differences in $\mathrm{EC}_{\mathrm{a}}$ were observed in this landscape: higher and more variable $\mathrm{EC}_{\mathrm{a}}$ data were collected in the wet spring than in the dry fall (Fig. 8; left-hand plots). On the $\mathrm{EC}_{\mathrm{a}}$ difference map (Fig. 8; right-hand plot), the $\mathrm{EC}_{\mathrm{a}}$ recorded in the fall has been subtracted from the $\mathrm{EC}_{\mathrm{a}}$ recorded in the spring. On this map, $\mathrm{EC}_{\mathrm{a}}$ increases throughout the catchment, but the change is most noticeable along the valley floor. Several weakly-expressed, linear patterns of relatively higher $\mathrm{EC}_{\mathrm{a}}$ extend up slope from the stream channel and identify the general locations of swales.

In soils that have low salt contents, $\mathrm{EC}_{\mathrm{a}}$ is strongly influenced by variations in clay and moisture contents (Brevik and Fenton, 2002; Carroll and Oliver, 2005; Johnson et al., 2001; Kachanoski et al., 1990). As a consequence, King et al. (2005) associated changes in $\mathrm{EC}_{\mathrm{a}}$ with changes in soil type and hydrology. Although absolute $\mathrm{EC}_{\mathrm{a}}$ values respond to temporal changes in soil moisture, most spatial $\mathrm{EC}_{\mathrm{a}}$ patterns remain temporally stable (Johnson et al., 2001; King et al., 2005; Sudduth et al., 2000). Collectively, the spatial EC $\mathrm{E}_{\mathrm{a}}$ patterns shown in Fig. 8 suggest two major, temporally-stable soil-landscape units within the catchment: the valley floor and higher-lying slope components. Lower and less variable $\mathrm{EC}_{\mathrm{a}}$ values were consistently recorded on the side slopes and summit areas where well-drained, shallow and moderately deep to shale bedrock soils are dominant; while higher and more variable $\mathrm{EC}_{\mathrm{a}}$ values were measured along the valley floor where somewhat poorly-drained, very deep soils are dominant. For the higher-lying slope components, the south-facing slopes displayed a 
greater variability in $\mathrm{EC}_{\mathrm{a}}$ and are known to be more hydrologically active than the north-facing slopes. Along the valley floor, the persistently higher $\mathrm{EC}_{\mathrm{a}}$ is attributed to higher clay content and wetter soil conditions.

\section{Summary}

Present EMI systems are suitable for use in soils investigations. In recent years, electromagnetic induction sensors have experienced a rapid succession of design improvements and have been successfully integrated with new technologies (e.g., field computers, PDAs, GPS receivers and DGPS technologies, Bluetooth) to become even more versatile and useful tools in soils research. The use of EMI to quickly and easily identify, characterize and map spatially-varying soil types and properties offers distinct advantages over traditional methods. This noninvasive geophysical tool can help facilitate the collection of large volumes of moderate to high resolution data, provide more comprehensive coverage of sites, and greater confidence in site assessments. However, results are site-specific and can vary depending on the complex interaction among multiple, interacting and variable soil properties. It is also important to note that $\mathrm{EC}_{\mathrm{a}}$ readings are a composite of soil properties; they cannot replace the detail provided by sampling and describing soils in the field. For this reason, ground-truthing of EMI data will remain important (Brevik and Hartemink, 2010) and EMI technologies will not completely replace trained field specialists (Brevik et al., 2006). Instead, traditional soil sampling and EMI techniques can be used together to provide even more information about the soils at a given site than is possible using either approach alone. Even with these challenges, $\mathrm{EC}_{\mathrm{a}}$ has been increasingly used to infer and map the spatial variability of soil properties at field and landscape scales.

\section{References}

Adamchuk, V.I., Hummel, J.W., Morgan, M.T., Upadhyaya, S.K., 2004. On-the-go soil sensors for precision agriculture. Comput. Electron. Agric. 44, 71-91.

Al-Gaadi, K., 2012. Employing electromagnetic induction techniques for the assessment of soil compaction. Am. J. Agric. Biol. Sci. 4, 425-434.

Allred, B.J., Ehsani, M.R., Saraswat, D., 2005. The impact of temperature and shallow hydrologic conditions on the magnitude and spatial pattern consistency of electromagnetic induction measured soil electrical conductivity. Trans. Am. Soc. Agric. Eng. 48 (6), 2123-2135.

Allred, B.J., Ehsani, M.R., Daniels, J.J., 2008. General considerations for geophysical methods applied to agriculture. In: Allred, B.J., Daniels, J.J., Ehsani, M.R. (Eds.), Handbook of Agricultural Geophysics. CRC Press, Taylor and Francis Group, Boca Raton, Florida, pp. 3-16.

Ammons, J.T., Timpson, M.E., Newton, D.L., 1989. Application of an aboveground electromagnetic conductivity meter to separate Natraqualfs and Ochraqualfs in Gibson County, Tennessee. Soil Surv. Horiz. 30, 66-70.

Anderson-Cook, C.M., Alley, M.M., Roygard, J.K.F., Khosla, R., Noble, R.B., Doolittle, J.A. 2002. Differentiating soil types using electromagnetic conductivity and crop yield maps. Soil Sci. Soc. Am. J. 66 (5), 1562-1570.

Batte, M.T., 2000. Factors influencing the profitability of precision farming systems. J. Soil Water Conserv. 55, 12-18.

Bekele, A., Hudnall, W.H., Daigle, J.J., Prudente, J.A., Wolcott, M., 2005. Scale dependent variability of soil electrical conductivity by indirect measures of soil properties. J. Terrramech. 42, 339-351.

Bianchini, A.A., Mallarino, A.P., 2002. Soil-sampling alternatives and variable-rate liming for a soybean-corn rotation. Agron. J. 94, 1355-1366.

Boettinger, J.L., Doolittle, J.A., West, N.E., Bork, E.W., Schupp, E.W., 1997. Non-destructive assessments of rangeland soil depth using electromagnetic induction. Arid Soil Res. Rehabil. 11, 375-390.

Bork, E.W., West, N.E., Doolittle, J.A., Boettinger, J.L., 1998. Soil depth assessment of sagebrush grazing treatments using electromagnetic induction. J. Range Manag. 51, 469-474.

Bourgault, R.R., Rabenhorst, M.C., 2012. Manganiferous soils in Maryland: regional extent and field-scale electromagnetic induction survey. Soil Sci. Soc. Am. J. 76 , $2128-2135$

Brevik, E.C., 2012. Analysis of the representation of soil map units using a common apparent electrical conductivity sampling design for the mapping of soil properties. Soil Surv. Horiz. 53 (2), 32-37.

Brevik, E.C., Batten, R.A., 2012. Evaluation of the FieldScout TDR300 for determining volumetric water content in sandy South Georgia Soils. Soil Horiz. 53 (6). http://dx.doi.org/10.2136/sh12-05-0018.

Brevik, E.C., Fenton, T.E., 1999. Improved mapping of the Lake Agassiz Herman Strandline by integrating geological and soil maps. J. Paleolimnol. 22 (3), 253-257.
Brevik, E.C., Fenton, T.E., 2002. The relative influence of soil water, clay, temperature, and carbonate minerals on soil electrical conductivity readings with an EM-38 along a Mollisol catena in central Iowa. Soil Surv. Horiz. 43, 9-13.

Brevik, E.C., Fenton, T.E., 2003. Use of the Geonics EM-38 to delineate soil in a loess over till landscape, southwestern Iowa. Soil Surv. Horiz. 44, 16-24.

Brevik, E.C., Fenton, T.E., 2004. The effect of changes in bulk density on soil electrical conductivity as measured with the Geonics ${ }^{\circledR}$ EM-38. Soil Surv. Horiz. 45, 96-102.

Brevik, E.C., Hartemink, A.E., 2010. Early soil knowledge and the birth and development of soil science. Catena 83, 23-33.

Brevik, E.C., Fenton, T.E., Jaynes, D.B., 2003. Evaluation of the accuracy of a central Iowa soil survey and implications for precision soil management. Precis. Agric. 4, 331-342.

Brevik, E.C., Fenton, T.E., Horton, R., 2004. Effect of daily soil temperature fluctuations on soil electrical conductivity as measured with the Geonics® EM-38. Precis. Agric. 5, 143-150

Brevik, E.C., Fenton, T.E., Lazari, A., 2006. Soil electrical conductivity as a function of soil water content and implications for soil mapping. Precis. Agric. 7, 393-404.

Brevik, E.C., Fenton, T.E., Jaynes, D.B., 2012. Use of electrical conductivity to investigate soil homogeneity in Story County, Iowa, USA. Soil Surv. Horiz. 53 (5), 50-54.

Cannon, M.E., McKenzie, R.C., Lachapelle, G., 1994. Soil salinity mapping with electromagnetic induction and satellite-based navigation methods. Can. J. Soil Sci. 74, 335-343.

Carroll, Z.L., Oliver, M.A., 2005. Exploring the spatial relations between soil physical properties and apparent electrical conductivity. Geoderma 128, 354-374.

Carter, L.M., Rhoades, J.D., Cesson, J.H., 1993. Mechanization of soil salinity assessment for mapping. Winter Meetings of the American Society of Agricultural Engineers, Paper No. 93-1557. American Society of Agricultural Engineers, St. Joseph, Michigan.

Cassel, F., Goorahoo, D., Zoldoske, D., Adhikari, D., 2009. Mapping soil salinity using ground-based electromagnetic induction. In: Metternicht, G., Zinck, J.A. (Eds.), Remote Sensing of Soil Salinization. CRC Press, Taylor and Francis Group, Boca Raton, Florida, pp. 199-233.

Chen, F.D., Kissel, E., Adkins, D., 2000. Mapping soil hardpans with penetrometer and electrical conductivity. 2000 ASAE Annual International Meeting, Technical Papers: Engineering Solutions for a New Century. American Society of Agricultural Engineers, St. Joseph, Michigan, pp. 2037-2048.

Cockx, L., Van Meirvenne, M., Vitharana, U.W.A., Verbeke, L.P.C., Simpson, D., Saey, T., Van Coille, F.M.B., 2009. Extracting topsoil information from EM38DD sensor data using neural network approach. Soil Sci. Soc. Am. J. 73 (6), 1-8.

Cook, P.G., Walker, G.R., 1992. Depth profiles of electrical conductivity from linear combinations of electromagnetic induction measurements. Soil Sci. Soc. Am. J. 56 1015-1022.

Cook, P.G., Hughes, M.W., Walker, G.R., Allison, G.B., 1989a. The calibration of frequencydomain electromagnetic induction meters and their possible use in recharge studies. J. Hydrol. 107, 251-265.

Cook, P.G., Walker, G.R., Jolly, I.D., 1989b. Spatial variability of groundwater recharge in a semiarid region. J. Hydrol. 111, 195-212.

Cook, P.G., Walker, G.R., Buselli, G., Potts, I., Dodds, A.R., 1992. The application of electromagnetic techniques to groundwater recharge investigations. J. Hydrol. 130, 201-229.

Corwin, D.L., 2008. Past, present, and future trends in soil electrical conductivity measurements using geophysical methods. In: Allred, B.J., Daniels, J.J., Ehsani, M.R. (Eds.) Handbook of Agricultural Geophysics. CRC Press, Taylor and Francis Group, Boca Raton, Florida, pp. 17-44.

Corwin, D.L., Rhoades, J.D., 1982. An improved technique for determining soil electrical conductivity - depth relations from above ground electromagnetic induction measurements. Soil Sci. Soc. Am. J. 46, 517-520.

Corwin, D.L., Rhoades, J.D., 1984. Measurements of inverted electrical conductivity profiles using electromagnetic induction. Soil Sci. Soc. Am. J. 48, 288-291.

Corwin, D.L., Rhoades, J.D., 1990. Establishing soil electrical conductivity - depth relations from electromagnetic induction measurements. Commun. Soil Sci. Plant Anal. 21 (11\&12), 861-901.

Daniels, J.J., Allred, B., Collins, M., Doolittle, J., 2003. Geophysics in soil science, In: Lal, R. (Ed.), Encyclopedia of Soil Science, Second edition. Marcel Dekker, New York, pp. 1-5.

de Jong, E., Ballantyne, A.K., Cameron, D.R., Read, D.L., 1979. Measurement of apparent electrical conductivity of soils by an electromagnetic induction probe to aid salinity surveys. Soil Sci. Soc. Am. J. 43, 810-812.

De Smedt, P., Van Meirvenne, M., Davies, N.S., Bats, M., Saey, T., Du Reu, J., Meerschman, E. Gelorini, V., Zwertvaegher, A., Antrop, M., Bourgeois, J., De Maeyer, P., Finke, P.A. Verniers, J., Crombé, P., 2013a. A multidisciplinary approach to reconstructing Late Glacial and Early Holocene landscapes. J. Archaeol. Sci. 40, 1260-1267.

De Smedt, P., Saey, T., Lehouck, A., Stichelbaut, B., Meerschman, E., Islam, M.M., Van De Vijver, E., Van Meirvenne, M., 2013b. Exploring the potential of multi-receiver EM survey for geoarchaeological prospection: A 90 ha dataset. Geoderma 199, 30-36.

Diaz, L., Herrero, J., 1992. Salinity estimates in irrigated soils using electromagnetic induction. Soil Sci. 154 (2), 151-157.

Doolittle, J.A., 2013. Technical Report on EMI and Saline Seep Workshop, Great Falls. USDA-NRCS-National Soil Survey Center, Lincoln, Nebraska, pp. 18-27 (August 12).

Doolittle, J.A., Sudduth, K.A., Kitchen, N.R., Indorante, S.J., 1994. Estimating depth to claypans using electromagnetic inductive methods. J. Soil Water Conserv. 49 (6) 552-555.

Doolittle, J., Murphy, R., Parks, G., Warner, J., 1996. Electromagnetic induction investigations of a soil delineation in Reno County, Kansas. Soil Surv. Horiz. 37, 11-20.

Doolittle, J.A., Indorante, S.J., Mitchell, P., Kingsbury, D.H., 1998. Where is it safe to build? Searching for geologic hazards in areas of karst. Conserv. Voices 1 (2), 14-19.

Doolittle, J., Noble, C., Leinard, B., 2000. An electromagnetic induction survey of a riparian area in southwest Montana. Soil Surv. Horiz. 41 (2), 27-36.

Doolittle, J.A., Peterson, M., Wheeler, T., 2001. Comparison of two electromagnetic induction tools in salinity appraisals. J. Soil Water Conserv. 56 (3), 257-262. 
Doolittle, J.A., Indorante, S.J., Potter, D.K., Hefner, S.G., McCauley, W.M., 2002a. Comparing three geophysical tools for locating sand blows in alluvial soils of southeast Missouri. J. Soil Water Conserv. 57 (3), 175-182.

Doolittle, J., Stube, A., Price, A., Kelly, G., 2002b. Mapping bedrock depths with EMI in Costilla County, Colorado. Soil Surv. Horiz. 43 (1), 14-21.

Doolittle, J.A., Neild, S.J., Sasser, L.D., Tuttle, J.W., 2005. Characterizing a lithosequence within the San Rafael Swell of Utah with EMI. Soil Surv. Horiz. 46 (4), 169-178.

Doolittle, J.A., Windhorn, R.D., Withers, D.L., Zwicker, S.E., Heisner, F.E., McLeese, B.L 2008. Soil scientists revisit a high-intensity soil survey in Northwest Illinois with electromagnetic induction and tradition methods. Soil Surv. Horiz. 49 (4) 102-108.

Doolittle, J.A., Windhorn, R.D., Withers, D.L., McLeese, R.L., 2009. High-intensity soil mapping with the aid of EMI in northern Illinois. Soil Surv. Horiz. 50 (2), 68-74.

Doolittle, J., Zhu, Q., Zhang, J., Guo, L., Lin, H., 2012. Geophysical investigations of soilandscape architecture and its impacts on subsurface flow. In: Lin, $\mathrm{H}$. (Ed.). Hydropedology: Synergistic Integration of Soil Science and Hydrology. Academic Press, Elsevier, pp. 413-447.

Doolittle, J., Chibirka, J., Muniz, E., Shaw, R., 2013. Using EMI and P-XRF to characterize the magnetic properties and the concentration of metals in soils formed ove different lithologies. Soil Horiz. 54 (3), 1-10. http://dx.doi.org/10.2136/sh13-010009.

Dunn, B.W., Beecher, H.G., 2007. Using electro-magnetic induction technology to identify sampling sites for soil acidity assessment and to determine spatial variability of soil acidity in rice fields. Aust. J. Exp. Agric. 47, 208-214.

Eigenberg, R.A., Doran, J.W., Nienaber, J.A., Ferguson, R.B., Woodbury, B.L., 2002. Electrica conductivity monitoring of soil condition and available $\mathrm{N}$ with animal manure and cover crop. Agric. Ecosyst. Environ. 88, 183-193.

Farahani, H.J., Flynn, R.L., 2007. Map quality and zone delineation as affected by width of parallel swaths with mobile agricultural sensors. Biosyst. Eng. 96 (2), 151-159.

Farahani, H.J., Buchleiter, G.W., Brodahl, M.K., 2005. Characterization of soil electrica conductivity variability in irrigated sandy and non-saline fields in Colorado. Trans. Am. Soc. Agric. Eng. 48 (1), 155-168.

Fenton, T.E., Lauterbach, M.A., 1999. Soil map unit composition and scale of mapping related to interpretations for precision soil and crop management in Iowa. Proceeding of the 4th International Conference on Precision Agriculture. American Society of Agronomy, Madison, Wisconsin, pp. 239-251.

Freeland, R.S., Yoder, R.E., Ammons, J.T., Leonard, L.L., 2002. Mobilized surveying of soil conductivity using electromagnetic induction. Appl. Eng. Agric. 18 (1), 121-126.

Frogbrook, Z.L., Oliver, M.A., 2007. Identifying management zones in agricultural fields using spatially constrained classification of soil and ancillary data. Soil Use Manag. 23, 40-51.

Ganjegunte, G.K., Braun, R.J., 2011. Delineating salinity and sodicity distribution in majo soil map units of El Paso, Texas, using electromagnetic induction technique. Soil Sci. 176 (8), 441-447.

Greenhouse, J.P., Slaine, D.D., 1983. The use of reconnaissance electromagnetic methods to map contaminant migration. Ground Water Monit. Rev. 3 (2), 47-59.

Greve, M.H., Greve, M.B., 2004. Determining and representing width of soil boundaries using electrical conductivity and MultiGrid. Comput. Geosci. 30, 569-578.

Harvey, O.R., Morgan, C.L.S., 2009. Predicting regional-scale soil variability using single calibrated apparent soil electrical conductivity model. Soil Sci. Soc. Am. J. 73, 164-169.

Hedley, C.B., Yule, I.J., Eastwood, C.R., Sheperd, T.G., Arnold, G., 2004. Rapid identification of soil textural and management zones using electromagnetic induction sensing in soils. Aust. J. Soil Res. 42, 389-400.

Heil, K., Schmidhalter, U., 2012. Characterisation of soil texture variability using apparent electrical conductivity at a highly variable site. Comput. Geosci. 39, 98-110.

Heilig, J., Kempenich, J., Doolittle, J., Brevik, E.C., Ulmer, M., 2011. Evaluation of electromagnetic induction to characterize and map sodium-affected soils in the Northern Great Plains. Soil Surv. Horiz. 52, 77-88.

Hezarjaribi, A., Sourell, H., 2007. Feasibility study of monitoring the total available wate content using non-invasive electromagnetic induction-based and electrode-based soil electrical conductivity measurements. Irrig. Drain. 56, 53-65.

Hopkins, D.G., Richardson, J.L., 1999. Detecting a salinity plume in an unconfined sandy aquifer and assessing secondary soil salinization using electromagnetic induction techniques, North Dakota, USA. Hydrogeol. J. 7, 380-392.

Huth, N.I., Poulton, P.L., 2007. An electromagnetic induction method for monitoring variations in soil moisture in agroforestry systems. Aust. J. Soil Res. 45, 6372.

James, I.T., Waine, T.W., Bradley, R.I., Taylor, J.C., Godwin, R.J., 2003. Determination of soil type boundaries using electromagnetic induction scanning techniques. Biosyst. Eng. 86 (4), 421-430.

Jaynes, D.B. 1995. Electromagnetic induction as a mapping aid for precision farming. Clean Water, Clean Environment, 21st Century: Team Agriculture. Working to Protect Water Resources. American Society of Agricultural Engineers, Kansas City, Missouri, pp. 153-156 (March 5 to 8).

Jaynes, D.B., 1996a. Improved soil mapping using electromagnetic induction surveys. In: Robert, P.C., Rust, R.H., Larson, W.E. (Eds.), Proceedings of the 3rd International Conference on Precision Agriculture. June 23-26, 1996, Minneapolis, Minnesota. American Society of Agronomy, Madison, Wisconsin, pp. 169-179.

Jaynes, D.B., 1996b. Mapping the areal distribution of soil parameters with geophysical techniques. Application of GIS to the modeling of non-point sources of pollution in the vadose zone. SSSA Special Publication, 48. Soil Science Society of America, Madison, Wisconsin, pp. 205-216.

Jaynes, D.B., Colvin, T.S., Ambuel, J., 1993. Soil type and crop yields determination from ground conductivity surveys. 1993 International Meeting of American Society of Agricultural Engineers. Paper No. 933552. American Society of Agricultural Engineers, St. Joseph, Michigan.
Jaynes, D.B., Novak, J.M., Moorman, T.B., Cambardella, C.A., 1994. Estimating herbicide partition coefficients from electromagnetic induction measurements. J. Environ. Qual. 24, 36-41.

Johnson, C.K., Doran, J.W., Duke, H.R., Wienhold, B.J., Eskridge, K.M., Shanahan, J.F., 2001. Field-scale conductivity mapping for delineating soil condition. Soil Sci. Soc. Am. J. 65, 1829-1837.

Johnston, M.A., Savage, M.J., Moolman, J.H., du Plessis, H.M., 1997. Evaluation of calibration methods for interpreting soil salinity from electromagnetic induction measurements. Soil Sci. Soc. Am. J. 61, 1627-1633.

Kachanoski, R.G., Gregorich, E.G., van Wesenbeeck, I.J., 1988. Estimating spatial variations of soil water content using noncontacting electromagnetic inductive methods. Can. J. Soil Sci. 68, 715-722.

Kachanoski, R.G., de Jong, E., van Wesenbeeck, I.J., 1990. Field scale patterns of soil water storage from non-contacting measurements of bulk electrical conductivity. Can. J. Soil Sci. 70, 537-541.

Khakural, B.R., Robert, P.C., Hugins, D.R., 1998. Use of non-contacting electromagnetic inductive method for estimating soil moisture across a landscape. Commun. Soil Sci. Plant Anal. 29 (11-14), 2055-2065.

King, J.A., Dampney, P.M.R., Lark, R.M., Wheeler, H.C., Bradley, R.I., Mayr, T.R., 2005. Mapping potential crop management zones within fields: use of yield-map series and patterns of soil physical properties identified by electromagnetic induction sensing. Precis. Agric. 6, 167-181.

Kitchen, N.R. Sudduth, K.A. Drummond, T.S., 1998. An evaluation of methods for determining site-specific management zones. Proceedings of the North Central Extension-Industry Soil Fertility Conference. Potash and Phosphate Institute, Brookings, South Dakota, pp. 133-139.

Korsaeth, A., Riley, H., Kværnø, S.H., Vestgarden, L.S., 2008. Relations between a commercial soil survey map based on apparent electrical conductivity $\left(\mathrm{EC}_{\mathrm{a}}\right)$ and measured soil properties on a moronic soil in southeast Norway. In: Allred, B.J., Daniels, J.J., Ehsani, M.R. (Eds.), Handbook of Agricultural Geophysics. CRC Press, Taylor and Francis Group, Boca Raton, Florida, pp. 225-231.

Kravchenko, A.N., 2008. Mapping soil drainage classes using topographic and soil electrical conductivity. In: Allred, B.J. Daniels, J. J. Ehsani, M.R. (Eds.), Handbook of Agricultural Geophysics. CRC Press, Taylor and Francis Group, Boca Raton, Florida, pp. 255-261.

Kravchenko, A.N., Bollero, G.A., Omonode, R.A., Bullock, D.G., 2002. Quantitative mapping of soil drainage classes using topographical data and soil electrical conductivity. Soil Sci. Soc. Am. J. 66, 235-243.

Kweon, G., 2012. Toward the ultimate soil survey: sensing multiple soil landscape properties in one pass. Agron. J. 104 (6), 1547-1557.

Lesch, S.M., Rhoades, J.D., Lund, L.J., Corwin, D.L., 1992. Mapping soil salinity using calibrated electromagnetic induction measurements. Soil Sci. Soc. Am. J. 56, 540-548.

Lesch, S.M., Strauss, DJ., Rhoades, J.D. 1995a. Spatial prediction of soil salinity using electromagnetic induction techniques. 1. Statistical prediction models: a comparison of multiple linear regression and cokriging. Water Resour. Res. 31, 373-386.

Lesch, S.M., Strauss, D.J., Rhoades, J.D., 1995b. Spatial prediction of soil salinity using electromagnetic induction techniques. 2. An efficient spatial sampling algorithm suitable for multiple linear regression model identification and estimation. Water Resour. Res. 31, 387-398.

Lesch, S.M., Herrero, J., Rhoades, J.D., 1998. Monitoring for temporal changes in soil salinity using electromagnetic induction techniques. Soil Sci. Soc. Am. J. 62, 232-242.

Lesch, S.M., Rhoades, J.D., Corwin, D.L., 2000. ESAP-95 version 2.10R User Manual and Tutorial Guide. Research Report 146. USDA-ARS George E. Brown, Jr. Salinity Laboratory, Riverside, California

Lobell, D.B., Lesch, S.M., Corwin, D.L., Ulmer, M.G., Anderson, K.A., Potts, D.J., Doolittle, J.A., Matos, M.R., Baltes, M.J., 2010. Regional-scale assessment of soil salinity in the Red River Valley using multi-year MODIS EVI and NDVI. J. Environ. Qual. 39, 35-41.

Lück, E., Gebbers, R., Ruehlmann, J., Sprangenberg, U., 2009. Electrical conductivity mapping for precision farming. Near Surf. Geophys. 7 (1), 15-25.

Mankin, K.R., Karthikeyan, R., 2002. Field assessment of saline seep remediation using electromagnetic induction. Trans. Am. Soc. Agric. Eng. 45 (1), 99-107.

Martinez, G., Vanderlinden, K., Ordóñez, R., Muriel, J.L., 2009. Can apparent electrical conductivity improve the spatial characterization of soil organic carbon? Vadose Zone J. 8 (3), 586-593.

McBride, R.A., Gordon, A.M., Shrive, S.C., 1990. Estimating forest soil quality from terrain measurements of apparent electrical conductivity. Soil Sci. Soc. Am. J. 54 (1), 290-293.

McKenzie, R.C., Chomistek, W., Clark, N.F., 1989. Conversion of electromagnetic inductance readings to saturated paste extract values in soils for different temperature, texture, and moisture conditions. Can. J. Soil Sci. 69, 25-32.

McNeill, J.D., 1980a. Electrical conductivity of soils and rock. Technical Note TN-5. Geonics Limited, Mississauga, Ontario, Canada.

McNeill, J.D., 1980b. Electromagnetic terrain conductivity measurement at low induction numbers. Technical Note TN-6Geonics Limited, Mississauga, Ontario, Canada.

Meerschman, E., Van Meirvenne, M., De Smedt, P., Saey, T., Islam, M.M., Meeuws, F., Van De Vijver, E., Ghysels, G., 2011a. Imaging polygonal network of ice-wedge casts with an electromagnetic induction sensor. Soil Sci. Soc. Am. J. 75 (6), 2095-2100.

Meerschman, E., Van Meirvenne, M., Van De Vijver, E., De Smedt, P., Saey, T., Islam, M.M., Saey, T., 2011b. Mapping complex soil patterns with multiple-point geostatistics. Eur. J. Soil Sci. 64, 183-191.

Mester, A., van der Kruk, J., Zimmermann, E., Vereecken, H., 2011. Quantitative two-layer conductivity inversion of multi-configuration electromagnetic induction measurements. Vadose Zone J. 10, 1319-1330.

Miller, B.A., 2012. The need to continue improving soil survey maps. Soil Horiz. 53, 11-15. 
Morris, E.R., 2009. Height-above-ground effects on penetration depth and response of electromagnetic induction soil conductivity meters. Comput. Electron. Agric. 68, 150-156.

Mueller, T.G., Hartsock, N.J., Stombaugh, T.S., Shearer, S.A., Cornelius, P.L., Barnhisel, R.I., 2003. Soil electrical conductivity map variability in limestone soils overlain by loess. Agron. J. 95, 496-507.

Nettleton, W.D., Bushue, L., Doolittle, J.A., Endres, T.J., Indorante, S.J., 1994. Sodiumaffected soil electrical identification in south-central Illinois by electromagnetic induction. Soil Sci. Soc. Am. J. 58, 1190-1193.

Palacky, G.J., Stephens, L.E., 1990. Mapping of Quaternary sediments in northeastern Ontario using ground electromagnetic methods. Geophysics 55, 1596-1604.

Rhoades, J.D., Corwin, D.L., 1981. Determining soil electrical conductivity-depth relations using an inductive electromagnetic soil conductivity meter. Soil Sci. Soc. Am. J. 45, 255-260.

Rhoades, J.D., Raats, P.A., Prather, R.J., 1976. Effects of liquid-phase electrical conductivity, water content, and surface conductivity on bulk soil electrical conductivity. Soil Sci. Soc. Am. J. 40, 651-655.

Rhoades, J.D., Lesch, S.M., Shouse, P.J., Alves, W.J., 1989a. New calibrations for determining soil electrical conductivity depth relations from electromagnetic measurements. Soil Sci. Soc. Am. J. 53, 74-79.

Rhoades, J.D., Manteghi, N.A., Shouse, P.J., Alves, W.J., 1989b. Soil Electrical conductivity and soil salinity: New formulation and calibrations. Soil Sci. Soc. Am. J. 53, 433-439.

Richardson, D.P., Williams, B.G., 1994. Assessing discharge characteristics of upland landscapes using electromagnetic induction techniques. Technical Memorandum 94/3. CSIRO Institute of Natural Resources and Environment, Division of Water Resources, Canberra, Australia.

Richardson, J.L., Wilding, L.P., Daniels, R.B., 1992. Recharge and discharge of groundwater in aquic conditions illustrated with flow analysis. Geoderma 53, 65-78.

Robinson, D.A., Binley, A., Crook, N., Day-Lewis, F.D., Ferré, T.P.A., Grauch, V.J.S., Knight, R., Knoll, M., Lakshmi, V., Miller, R., Nyquist, J., Pellerin, L., Singha, K., Slater, L., 2008. Advancing process-based watershed hydrological research using near-surface geophysics: a vision for, and review of, electrical and magnetic geophysical methods. Hydrol. Process. 22, 3604-3635.

Saey, T., Simpson, D., Vitharana, U.W.A., Vermeersch, H., Vermang, J., Van Meirvenne, M. 2008. Reconstructing the paleotopography beneath the loess cover with the aid of electromagnetic induction sensors. Catena 74, 58-64.

Saey, T., Simpson, D., Vermeersch, H., Cockx, L., Van Meirvenne, M., 2009a. Comparing the EM38DD and DUALEM-21S sensors for depth-to-clay mapping. Soil Sci. Soc. Am. J. 73 (1), 7-12.

Saey, T., Van Meirvenne, M., Vermeersch, H., Ameloot, N., Cockx, L., 2009b. A pedotransfer function to evaluate the soil profile textural heterogeneity using proximally sensed apparent electrical conductivity. Geoderma 150, 389-395.

Saey, T., De Smedt, P., De Clercq, W., Meerschman, E., Islam, M.M., Van Meirvenne, M., 2012a. Identifying soil patterns at different spatial scales with a multi-receiver EMI sensor. Soil Sci. Soc. Am. J. 77, 382-390.

Saey, T., De Smedt, P., Monirul Islam, M., Meerschman, E., Van De Vijver, E., Lehouck, A., Van Meirvenne, M., 2012b. Depth slicing of a multi-receiver EMI measurements to enhance the delineation of contrasting soil features. Geoderma 189-190, 514-521.

Saey, T., Van Meirvenne, M., De Smedt, P., Neubauer, W., Trink, I., Verhoeven, G., Seren, S. 2013. Integrating multi-receiver electromagnetic induction measurements into the interpretation of the soil landscape around the school of gladiators at Carnuntum. Eur. J. Soil Sci. 64, 716-727.

Scanlon, B.R., Paine, J.G., Goldsmith, R.S., 1999. Evaluation of electromagnetic induction as a reconnaissance technique to characterize unsaturated flow in an arid setting. Ground Water 37 (2), 296-304.

Schumann, A.W., Zaman, Q.U., 2003. Mapping water table depth by electromagnetic induction. Appl. Eng. Agric. 19 (6), 675-688.

Shaner, D.L., Kosla, R., Brodahl, M.K., Buchleiter, G.W., Farahani, H.J., 2008. How well do zone sampling based soil electrical conductivity maps represent soil variability? Agron. J. 100 (5), 1472-1480.

Sheets, K.R., Hendrickx, J.M.H., 1995. Noninvasive soil water content measurements using electromagnetic induction. Water Resour. Res. 31, 2401-2409.

Sherlock, M.D., McDonnell, J.J., 2003. A new tool for hillslope hydrologists: spatially distributed groundwater level and soil water content measured using electromagnetic induction. Hydrol. Process. 17, 1965-1977.

Slavich, P.G., 1990. Determining $\mathrm{EC}_{\mathrm{a}}$-depth profiles from electromagnetic induction measurements. Aust. J. Soil Res. 28, 443-452.

Slavich, P.G., Yang, J., 1990. Estimation of field scale leaching rates from chloride mass balance and electromagnetic induction measurements. Irrig. Sci. 11, 7-14.

Soil Survey Division Staff, 1993. Soil survey manual. USDA Agricultural Handbook No. 18US Government Printing Office, Washington, DC.

Sommer, M., Wehrhan, M., Zipprich, M., Weller, U., Castell, W.Zu., Ehrich, S., Tandler, B., Selige, T., 2003. Hierarchical data fusion for mapping soil units at field scale. Geoderma 112, 179-196

Stroh, J., Archer, S.R., Wilding, L.P., Doolittle, J., 1993. Assessing the influence of subsoil heterogeneity on vegetation patterns in the Rio Grande Plains of south Texas using electromagnetic induction and geographical information system. The Station, College Station, TX 39-42 (Mar 93).

Sudduth, K.A., Kitchen, N.R., 1993. Electromagnetic induction sensing of claypan depth. Winter Meetings of the American Society of Agricultural Engineers, Paper No. 93-1550. American Society of Agricultural Engineers, St. Joseph, Michigan.

Sudduth, K.A., Kitchen, N.R., Hughes, D.H., Drummond, S.T., 1995. Electromagnetic induction sensing as an indicator of productivity on claypan soils. In: Robert, P.C., Rust, R.H., Larson, W.E. (Eds.), Proceedings of Second International Conference on Precision Management for Agricultural Systems. March 27-30, 1994, Minneapolis, Minnesota. American Society of Agronomy, Madison, Wisconsin, pp. 671-681.
Sudduth, K., Kitchen, N.R., Drummond, S., 1999. Soil conductivity sensing on claypan soils: Comparison of Electromagnetic Induction and direct methods. Proceedings of the 4th International Conference on Precision Agriculture. ASA, CSSA and SSSA, Madison, Wisconsin, pp. 979-990.

Sudduth, K.A., Drummond, S.T., Kitchen, N.R., 2000. Measuring and interpreting soil electrical conductivity for precision agriculture. Proc. Int. Conference Geospatial Information in Agriculture and Forestry. Lake Buena Vista, Florida. June 10-12, 2000. ERIM International, Inc., Ann Arbor, MI, pp. 1444-1451.

Sudduth, K., Drummond, S., Kitchen, N.R., 2001. Accuracy issues in electromagnetic induction sensing of electrical conductivity for precision agriculture. Comput. Electron. Agric. 31, 239-264.

Sudduth, K.A., Kitchen, N.R., Bollero, G.A., Bullock, D.G., Wiebold, W.J., 2003. Comparison of electromagnetic induction and direct sensing of soil electrical conductivity. Agron. J. 95, 472-482.

Sudduth, K.A., Kitchen, N.R., Myers, D.B., Drummond, S.T., 2009. Estimating depth to argillic soil horizons using apparent electrical conductivity response functions. Proceedings of the Symposium on the Application of Geophysics to Engineering and Environmental Problems, 2. SAGEEP, pp. 859-868.

Sudduth, K., Kitchen, N.R., Chung, S.-O., Drummond, S.T., 2010. Site-specific compaction, soil physical property, and crop yield relationships for claypan soils. Annual International Meeting of American Society of Agricultural and Biological Engineers. Paper No. 1009432. American Society of Agricultural and Biological Engineers, St. Joseph, Michigan.

Thomas, M., Fitzpatrick, R.W., Heinson, G.S., 2009. Distribution and causes of intricate saline-sodic soil patterns in an upland South Australian hillslope. Soil Res. 47 (3), 328-339.

Toushmalani, R., 2010. Application of geophysical methods in agriculture. Aust. J. Basic Appl. Sci. 4 (12), 6433-6439.

Triantafilis, J., Monteiro Santos, F.A., 2013. Electromagnetic conductivity imaging (EMCI) of soil using a DUALEM-421 and inversion modeling software (EM4Soil). Geoderma 211-212, 28-38.

Triantafilis, J., Lesch, S.M., La Lau, K., Buchanan, S.M., 2009. Field level digital mapping of cation exchange capacity using electromagnetic induction and a hierarchical spatial regression model. Aust. J. Soil Res. 47, 651-663.

Triantafilis, J., Terhune IV, C.H., Monteiro Santos, F.A., 2013. An inversion approach to generate electromagnetic conductivity images from signal data. Environ. Model Softw. 43, 88-95.

Tromp-van Meerveld, H.J., McDonnell, J.J., 2009. Assessment of multi-frequency electromagnetic induction for determining soil moisture patterns at the hillslope scale. J. Hydrol. 368, 56-67.

United States Department of Agriculture, Natural Resources Conservation Service, 2006 Land resource regions and major land resource areas of the United States, Caribbean, and Pacific Basin. USDA Handbook 296.

United States Salinity Laboratory Staff, 1954. Diagnosis and improvement of saline and alkali soils. USDA Agricultural Handbook No. 60US Government Printing Office, Washington, DC

Urdanoz, V., Aragüés, R., 2012. Comparison of Geonics EM38 and Dualem 1S electromagnetic induction sensors for the measurement of salinity and other soil properties. Soi Use Manag. 28, 108-112.

van der Lelij, A., 1983. Use of Electromagnetic Induction Instrument (type EM-38) for Mapping Soil Salinity. Water Resources Commission, Murrumbidgee Division, New South Wales, Australia.

Van Meirvenne, M., Islam, M.M., De Smedt, P., Meerschman, E., Van De Vijver, E., Saey, T., 2013. Key variables for the identification of soil management classes in the aeolian landscapes of north-west Europe. Geoderma 199, 99-105.

Vitharana, U.W.A., Saey, T., Cockx, L., Simpson, D., Vermeersch, H., Van Meirvenne, M. 2008a. Upgrading a 1/20,000 soil map with an apparent electrical conductivity survey. Geoderma 148, 107-112.

Vitharana, U.W.A., Van Meirvenne, M., Simpson, D., Cockx, L., De Baerdemaeker, J., 2008b. Key soil and topographic properties to delineate potential management classes for precision agriculture in the European loess area. Geoderma 143, 206-215.

Waine, T.W., Blackmore, B.S., Godwin, R.J., 2000. Mapping available water content and estimating soil textural class using electromagnetic induction. EurAgEng Pape No. 00-SW-044, Warwick, United Kingdom.

Weller, U., Zipprich, M., Sommer, M., Castell, W.Zu., Wehrhan, M., 2007. Mapping clay content across boundaries at the landscape scale with electromagnetic induction. Soil Sci. Soc. Am. J. 71 (6), 1740-1747.

White, M.L., Shaw, J.N., Raper, R.L., Rodekohr, D., Wood, C.W., 2012. A multivariate approach for high-resolution soil survey development. Soil Sci. 177 (5), 345-354.

Wienhold, B.J., Doran, J.W., 2008. Apparent electrical conductivity for delineating spatial variability in soil properties. In: Allred, B.J., Daniels, J.J., Ehsani, M.R. (Eds.), Handbook of Agricultural Geophysics. CRC Press, Taylor and Francis Group, Boca Raton, Florida, pp. 211-215.

Williams, B.G., Arunin, S., 1990. Inferring recharge/discharge areas from multifrequency electromagnetic induction measurements. CSIRO Division of Water Resources, Tech Memorandum 90/11 (November).

Williams, B.G., Baker, G.C., 1982. An electromagnetic induction technique for reconnaissance surveys of soil salinity hazards. Aust. J. Soil Res. 20, 107-118.

Williams, B.G., Hoey, D., 1987. The use of electromagnetic induction to detect the spatial variability of the salt and clay contents of soils. Aust. J. Soil Res. 25, 21-27.

Williams, B., Walker, J., Anderson, J., 2006. Spatial variability of regolith leaching and salinity in relation to whole farm planning. Aust. J. Exp. Agric. 46, 1271-1277.

Wollenhaupt, N.C., Richardson, J.L., Foss, J.E., Doll, E.C., 1986. A rapid method for estimating weighted soil salinity from apparent soil electrical conductivity measured with an aboveground electromagnetic induction meter. Can. J. Soil Sci. $66,315-321$. 
Zalasiewicz, J.A., Mathers, S.J., Cornwell, J.D., 1985. The application of ground conductivity measurements to geological mapping. Q. J. Eng. Geol. Hydrogeol. $18,139-148$

Zhu, Q., Lin, H.S., Doolittle, J., 2010a. Repeated electromagnetic induction surveys for determining subsurface hydrologic dynamics in an agricultural landscape. Soil Sci. Soc. Am. J. 74, 1750-1762.
Zhu, Q., Lin, H.S., Doolittle, J., 2010b. Repeated electromagnetic induction surveys for improving soil mapping in an agricultural landscape. Soil Sci. Soc. Am. J. 74, 1763-1774.

Zhu, Q., Liao, K., Xu, Y., Yang, G., Wu, S., Zhou, S., 2013. Monitoring and prediction of soil moisture spatial-temporal variations from a hydropedological perspective: a review. Soil Res. 50 (8), 625-637. 